\title{
STUDIES ON DISEASE RESISTANCE
}

\section{A TOBACCO RESISTANT TO ORDINARY TOBACCO MOSAIC.*}

\author{
J. A. B. Nolis, Ph. D.** \\ Assistant Commissioner of Agriculture
}

\section{INTRODUCTION}

The field of immunity and resistance to pathogens in plants is one of unusual interest and of great promise. In plants, unlike animals, efforts directed to the induction of acquired immunity have been unsuccessful, except perhaps in the case of the ring-spot of tobaceo: Price (22) and the aucuba mosaic of tomato on Nicotiana sylvestris: Kunkel (18). In the former the virus is present in the tissues which fail to produce necrotic lesions upon a second inoculation and this peculiar reaction is systemic; in the latter immunity against the aucuba mosaic virus results from infection with the ordinary tobaccomosaic virus and such immunity is restricted to the areas invaded by the latter.

It seems quite improbable that pathologists will find in this phase of immunity a practical answer to the problems of plant disease control. Natural inherent immunity should be a logical way of protecting the higher plants from their pathogens. Strains of some of our important crop plants exhibiting a high degree of tolerance or resistance to disease have been discovered in various regions of the world and these plants have been the basis for researches on the nature of disease resistance and on the development of new varieties of crop plants resistant to one or more diseases.

Last year the writer and Roque (21) announced the discovery of the mosaic resistance of the Colombian Ambalema tobacco (Nicotiana tabacum L.); but no account was given of the details of the experiments.

The purpose of this paper is to present the results and observations on infection studies with this variety of tobacco.

The investigation was begun in Puerto Rico in 1929-30 and continued at the University of Cornell (1930-1932) and the University of Winsconsin (1932-1933).

\footnotetext{
* Accepted for publication October 1934.

** John Simon Guggenheim Memorial Foundation Fellow. Latin American Exchange. July 1932-Sept. 1933.
} 


\section{Materials and Methods}

The resistant variety Ambalema was the basis of all the studies; but Turkish Tobaceo, var. Samsun, "Ceniza", "Consolation" and Connecticut Havana No. 38 were used as checks. The variety Samsun was used as one of the parents of the cross with the resistant tobacco. This variety has been in our collection since 1928 and was obtained through the courtesy of Mr. John Steele of the Puerto Rican Leaf Tobacco Co. of San Juan, who had received it from Greece. The variety Havana No. 38 was obtained from Professor James Johnson of the University of Wisconsin. The yellow tobaceo "Consolation", like the gloucous ("Ceniza") variety, originated in Puerto Rico probably by mutation from one of the ordinary filler types. The Nicotiana glutinosa L. employed in this investigation was obtained from Professor Johnson.

The tobaceo plants used for purposes of determining susceptibility or resistance to mosaic were grown in three or four-inch pots, in fertile soil compost.

The tobaceo plants were first inoculated when very small, at about the stage of development described by Johnson (10); namely, "with only two to four leaves large enough to be inoculated." Some of the resistant plants were remov'ed to slightly colder greenhouses after notes were taken on the results of a second inoculation. All plants regarded as resistant were inoculated three times at intervals of 7-10 days.

The $N$. glutinosa plants were similarly grown in warm greenhouses. These were planted in four-inch pots and topped down to eight or nine leaves. Topping favors expansion of the leaves. When inoculated each plant supported at least six good sized, sound leaves.

The rubbing or wiping method described by Holmes (8) was employed in all inoculations on tobaceo or $N$. glutinosa. Leaf material was crushed in sterile mortars in the customary way.

The presence of the virus in a resistant plant or its concentration therein was determined by rubbing the freshly extracted juices on $N$. glutinosa or on small tobaceo plants. The production of the typical symptoms of ordinary tobacco mosaic on young tobaceo plants or the production of lesions on $N$. glutinosa were considered as evidence of the presence of the virus in the resistant plant.

The concentration of the virus particles in infected plants has been generally determined, on the basis of Holmes' method, by making counts of the local lesions produced on $N$. glutinosa leaves, taking as a measure the number of lesions per leaf. It occurred to the writer 
that since the higher or lower rate of growth of the $N$. glutinosa plant may determine a larger or smaller number of lesions per leaf, the results obtained in different laboratories would hardly be comparable. Holmes' method presupposes unit areas but does not take care of the factor of differential rate of growth. Consequently, the number of local lesions produced per measured unit area on $N$. glutinosa was taken in this investigation as the measure of the concentration of the virus. Five leaves of $N$. glutinosa were employed for each observation. The area was measured on the third day after inoculation, when counts of lesions were made, and the number of local lesions per every $10 \mathrm{sq}$. cm. of leaf surface was taken as an index of the virus concentration. In measuring the area of leaves the following procedure was observed throughout. The leaves were outlined on a book so that a permanent record was obtained. The area was then measured from the paper with the aid of a planimeter.

The virus cultures employed in this investigation were obtained as follows: the ordinary tobacco-mosaic virus (tobacco virus 1) as used by Grant (7) in his studies of the suscept range of the tobaccomosaic virus; the viruses of yellow tobaceo mosaic, cucumber mosaic, yellow cucumber mosaic, potato ring-spot, Wingard's tobacco ringspot, eelery mosaic, veinbanding, and mottle were obtained from Professor Johnson's Laboratory. In the early stages of these studies we used a culture of the tobacco-mosaic virus isolated from diseased material from Puerto Rico.

The thermal inactivation point of the viruses was determined in 5 c.c. samples of freshly extracted juices by subjecting them to the desired temperatures for ten minutes, as described by Johnson (12). In the statistical study of the significance of results, Student's method for paired results and Bessel's method were employed throughout. In general, odds lower than 31.36 to 1 were considered as meaning that the deviations observed might be considered as being caused by chance alone.

\section{Experimental Results}

Infection of the resistant variety.-As a general rule, when large plants of the Colombian variety Ambalema are inoculated with the virus of the ordinary tobacco mosaic no appreciable visible symptoms appear on leaves or on the suckers of the inoculated plants. If such plants are examined when in a rapidly growing condition, a very mild mottling may be observed in the younger leaves of some individuals. At the beginning, plants older than six or seven weeks 
were employed and, therefore, considerable doubt arose as to whether infection with the mosaic virus had taken place. Roque (23) has stated that no infection occurred in 686 inoculations that he made. The writer is satisfied that those observations were on large plants on which the symptoms must not have been evident. In the present trials plants of all ages were inoculated with the virus and it has been found that infection occurred in every instance irrespective of size of plant.

On small plants.-The first experiment to determine the production of visible symptoms of ordinary tobacco mosaic on small plants of the resistant strain, consisted of the inoculation of ten plants. Five plants each of "Ceniza", "Consolation", Turkish and Havana No. 38 were used as checks. At the end of two weeks the typical symptoms of the disease were very evident on all the checks. On the resistant variety clearing of the veins occurred and was followed by interveinal small chlorotic areas of a mild type, which appeared by the ninth day and became more evident at the end of two weeks. (See figs. 1-7 and 10-14.) These plants and checks of the Turkish variety were transferred to six-inch pots and finally to ten-inch pots and kept until blossoming time. Soon after transferring to the large pots the symptoms disappeared from the resistant plants and these reached normal development. The check plants remained stunted and numerous lesions were evident on the older leaves. During the course of this investigation a total of 373 small plants of the Ambalemo variety and adequate checks were inoculated and studied. It is concluded from the experiment that young plants of the Ambalema variety become infected with the ordinary tobacco-mosaic virus as shown by symptoms and presence of the virus in the tissues but that infected plants apparently recover from the disease as is indicated by subsequent normal growth and disappearance of symptoms.

On large plants.-Plants 4, 6 and 8 weeks old were inoculated in order to determine susceptibility to infection. Clearing of veins was noted at the end of five to seven days on the 4-week old plants. but it soon disappeared. (See figs. 8 and 9.) No visible symptoms were noted on the older plants. In order to determine if these plants had become infected the juice from the inoculated leaf and the three successive leaves was extracted separately and $N$. glutinosa and check plants inoculated with it. Necrotic local lesions appeared on $N$. glutinosa and typical symptoms developed on the check susceptible tobacco plants indicating the presence of the mosaic virus in the tissues of the inoculated plants. 
On transplants.-An experiment was made with the purpose of ascertaining whether infection occurs in plants of the age at which they are ordinarily transplanted into the field. Four-week-old seedlings were pulled and treated as follows: (a) 100 Ambalema and 25 susceptible seedlings inoculated with the mosaic virus; (b) 25 Ambalema and 25 susceptible seedlings left uninoculated. All were transplanted into 4-inch pots. At the end of 7-10 days mild symptoms were discovered on the inoculated Ambalema plants, severe symptoms on young leaves of susceptible plants, and no change on the uninoculated Ambalema and susceptible plants. At the end of four weeks, only the lower leaves of inoculated Ambalema plants showed a very faint mottling; the inoculated susceptible plants were severely affected with mosaic and were discarded. All the inoculated Ambalema plants and ten each of uninoculated Ambalema and susceptible plants were planted in the garden and observations made until blossoming had occurred. The extracted juices from the inoculated plants when inoculated to $N$. glutinosa plants showed the presence of the virus in those plants. Judging from type and rapidity of growth, the inoculated Ambalema plants made as normal a development as the uninoculated Ambalema plants. The susceptible uninoculated plants became infected after transplanting in the garden. The experiment proves that in the case of the resistant tobacco, even though infection occurs during transplanting, the plants will not be seriously affected and will recover from the disease although the virus may be present in the tissues.

Reaction of the Ambalema tobacco to other viruses.-It was deemed of considerable interest to determine the reaction of this tobaceo to other viruses known to infect ordinary tobacco. This variety of tobacco would have been of unique value if it had turned out to be resistant to these viruses. Lots of ten plants were each inoculated with the virus of the following diseases: cucumber mosaic, yellow cucumber mosaic, potato ring-spot (healthy potato virus) Wingard's tobaceo ring-spot, veinbanding, mottle (healthy potato virus), veinbanding plus potato ring-spot (spot necrosis), celery mosaic, yellow tobaceo mosaic, and the ordinary tobaceo mosaic as a check. The results were as follows:

(a) The cucumber and the yellow cucumber mosaic viruses infected the plants very virulently producing much malformation and a very conspicuous pattern on the leaves. (See figs. 17, 18, 20 and 22.) 
(b) Potato ring-spot. The ring-spot virus obtained from apparently healthy potatoes and proved by Johnson (10) to cause a peculiar ring-spot disease on tobacco, can infect the Ambalema tobacco and produce the typical symptoms on the leaves. Infected plants did not recover under the conditions of the warm greenhouse; the plants became stunted and were finally destroyed.

(c) Tobacco ring-spot.-The virus of the ring-spot of tobacco, reported by Fromme, Wingard, and Priode (5) as an infectious disease, produces a very virulent infection on the Ambalema tobacco. The symptoms appear on the third day after inoculation and infection becomes readily systemic in the plants. Severe defoliation ensues and attempts of infected plants at new vegetative growth are quickly frustrated by the necrotic ring spots which extend over the blades of open or unfolding leaves. The infection is much more sev'ere than that produced by the potato ring-spot virus. Plants do not recover from infection. (See fig. 16.)

(d) Mottle.-The virus obtained from healthy potatoes and producing a mottling in tobaceo (Johnson : 10) unlike that induced by the ordinary tobacco-mosaic virus, was found to infect the Ambalema variety. The symptoms were similar to those observed on the check Havana No. 38 plants. The plants seemed to be little affected by the disease even though the characteristic symptoms appeared successively in the new growth.

(e) Veinbanding.-The veinbanding virus, one of the factors responsible for the rugose mosaic of the potato, when inoculated into Ambalema plants produces symptoms similar to those produced by the same virus on other tobacco plants. In our experiments, the clearing of the veins while not as striking as that produced by infection of the check Havana No. 38 plants, did not fade away, as in the case of the clearing of the veins which results consequent to infection with the ordinary tobacco mosaic.

(f) Spot-necrosis.-This disease of tobacco, first described by Johnson (10) and suggested by him (13) as identical with the rugose mosaic of potato was definitely established by Koch $(16,17)$ to be a combination of the mottle obtained from apparently healthy potatoes and the insect-transmitted veinbanding. Koch (17) further demonstrated that the spot- necrosis could be produced by a combination of the potato ring-spot virus and the veinbanding virus. This combination was inoculated into the Ambalema plants. Infection oc- 
curred and on the third day necrosis of the leaf tissue was well under way. Within a week, most of the leaves had been involved. The plants were transplanted into large pots and removed to a slightly colder greenhouse. Leaves showed necrotic lesions while still unfolded, and the plants finally succumbed to infection. It can be stated without hesitation that the severest infection was produced by this combination of viruses.

(g) Celery mosaic.-The virus causing a mosaic in celery and described by Wellman (26) as celery virus 1, produced symptoms on Ambalema which are somewhat similar to those produced on Havana No. 38 tobacco plants. The plants, however, seem to be able to grow to maturity even though somewhat stunted.

(h) The yellow tobacco-mosaic virus produced infection on Ambalema plants and visible symptoms were evident by the sixth day after inoculation. These appeared in the form of small yellow areas which in many instances were bordered by a lesion-like zone (See fig. 15). The yellow areas seemed to be more conspicuous and frequent along and near the margin of the leaves. The infected plants were evidently more seriously affected than similar plants inoculated with the ordinary tobacco-mosaic virus. This point may be of interest since the difference between the yellow tobacco-mosaic virus and that causing ordinary tobacco mosaic have not been clearly defined. The affected plants were able to attain full development even though exhibiting the small mosaiced areas.

\section{Degree of Resistance}

It has been stated above that infection in the resistant variety occurs whenever plants are properly inoculated, that the symptoms appear only mildly in small plants and that recovery seems to develop with age. In order to determine in a fairly quantitative way the degree of resistance of the resistant plants, a comparison was made on the basis of the virus concentration in Ambalema and susceptible (Havana No. 38) plants of different sizes and ages as indicated by the number of local lesions produced on Nicotiana glutinosa. The concentrated juice extract from the leaves of plants of corresponding age was employed in the tests. The results appear in tables I, II and III. In every case the number of lesions in the tables corresponds to a different plant. The significance of the differences is determined by Student's method. 
TABLE I.-CONCENTRATION OF THE VIRUS IN THE JUICE OF AMBALEMA \& HA VANA No. 38 PLANTS, FIVE WEEKS OLD; JUICE EXTRACTED ONE WEEK AFTER INOCULATION; LESIONS PER $10 \mathrm{sQ.} \mathrm{CM.} \mathrm{OF} \mathrm{N.} \mathrm{GLUTINOSA} \mathrm{LEAF} \mathrm{SURFACE.}$

\begin{tabular}{|c|c|c|c|c|}
\hline Ambalema & $\begin{array}{c}\text { Havana } \\
\text { No. } 38\end{array}$ & $\mathrm{~d}^{2}$ & $\mathrm{M}$ & S. D. \\
\hline \multirow[t]{2}{*}{ 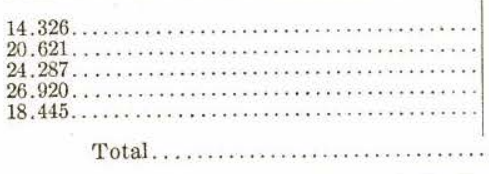 } & $\begin{array}{l}90.324 \\
91.258 \\
86.326 \\
97.216 \\
83.717\end{array}$ & $\begin{array}{r}3.119 \\
12.924 \\
148.669 \\
528.264 \\
80.282\end{array}$ & 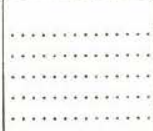 & 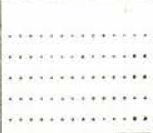 \\
\hline & $\ldots \ldots \ldots \ldots$ & 773.258 & 74.232 & 12.4359 \\
\hline
\end{tabular}

The value of $Z$ was found to be 5.97. The odds were determined from the table on the values of $Z$. With this number of observations and $\mathrm{Z}$ taken as 6.0 , the odds were found to be higher than $9999: 1$ against a difference as great as 74.232 occurring due to chance alone. Therefore this experiment shows a difference in resistance between Ambalema and Havana No. 38 at an age of five weeks.

TABLE II-CONCENTRATION OF THE VIRUS IN THE JUICE OF AMBALEMA AND HAVANA No. 38 PLANTS, 9 WEEKS OLD; JUICE EXTRACTED FOUR WEEKS AFTER INOCULATION; LESIONS PER 10 SQ. CM. OF N. GLUTINOSA LEAF SURFACE

\begin{tabular}{|c|c|c|c|c|}
\hline Ambalema & $\begin{array}{c}\text { Havana } \\
\text { No. } 38\end{array}$ & $d^{2}$ & M & S. D. \\
\hline 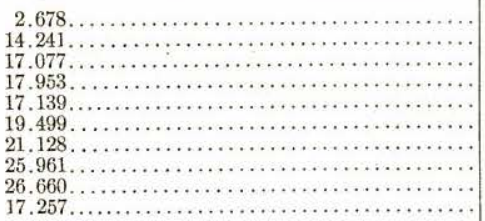 & $\begin{array}{l}35.083 \\
86.766 \\
68.909 \\
91.461 \\
67.767 \\
55.925 \\
38.161 \\
56.553 \\
49.441 \\
57.769\end{array}$ & $\begin{array}{r}108.556 \\
882.149 \\
291.624 \\
63.250 \\
60.902 \\
40.934 \\
665.176 \\
149.622 \\
401.722 \\
5.345\end{array}$ & 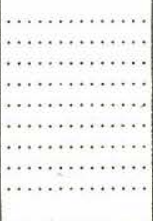 & 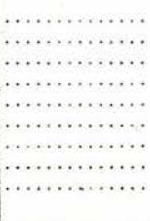 \\
\hline Total.... & & 2,669280 & 42.824 & 16.3379 \\
\hline
\end{tabular}

The value of $\mathrm{Z}$ was found to equal 2.6 which for this number of observations shows odds higher than $9999: 1$, indicating that the difference 42.824 is not due to chance alone. Ambalema plants at an age of nine weeks are more resistant than equally old Havana No. 38 plants. 
TABLE III-CONCENTRATION OF THE VIRUS IN THE JUICE OF $A M B A L E M A$ AND HAVANA No. 38 PLANTS, 13 WEEKS OLD; JUICE EXTRACTED NINE WEEKS AFTER INOCULATION; LESIONS PER $10 \mathrm{SQ}$. CM. OF N. GLUTINOSA LEAF SURFACE.

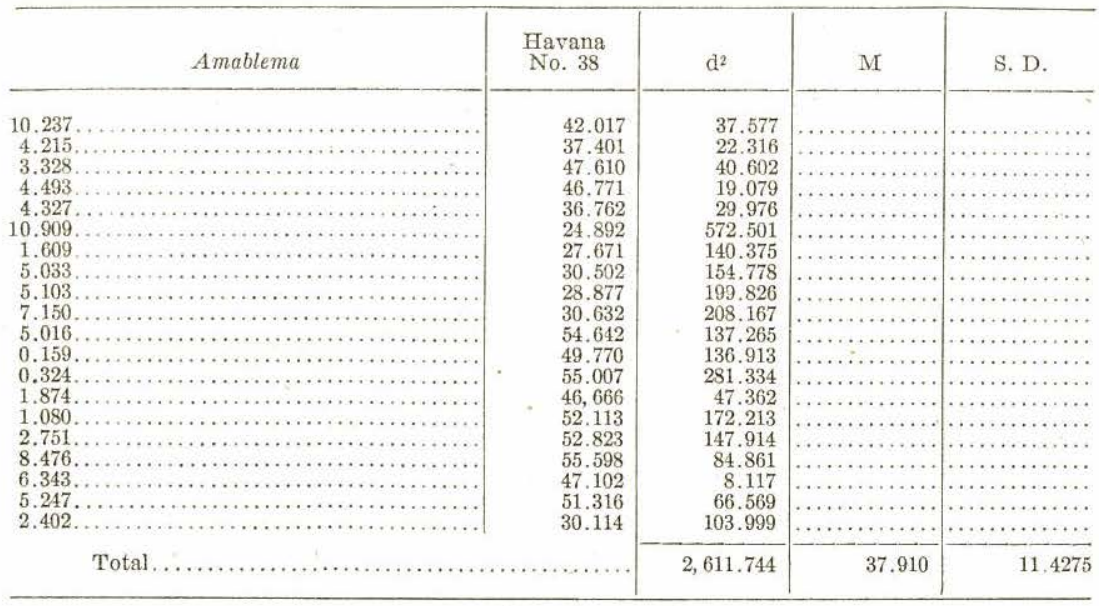

The value of $Z$ is 3.317 , which with $n=20$, gives odds higher than $9999: 1$ that the difference is not due to chance alone. Therefore, it may be concluded that the lower concentration of the virus in the resistant plant may be considered as meaning that a quantitative difference in resistance exists between the Ambalema and the Havana No. 38 tobaceo plants of thirteen weeks of age.

The results given above seem to show that a difference in resistance to ordinary tobaceo mosaic exists between the Ambalema and the Havana No. 38 tobaceo varieties, as measured by the number of local lesions produced on $N$. glutinosa leaves by the extracted juice of inoculated plants of corresponding age and size. This difference in resistance is expressed in terms of lesions per ten square centimeters of leaf surface of $N$. glutinosa.

Using Bessel's method for the determination of the probable error the difference in concentration of the ordinary tobacco-mosaic virus in the Ambalema and Havana No. 38 potted plants, was also found to be significant. The mean concentration of the virus in Havana No. 38 was $45.458 \pm 2.292$ lesions per 10 square centimeters of $N$. glutinosa leaf surface (Table IV); that for the virus in Ambalema plants was $4.828 \pm 0.468$ lesions (Table VI). The difference 40.63 \pm 2.34 is clearly not due to chance alone and indicates that on the basis of the number of lesions produced by the plant extracts on N. glutinosa, the Ambalema variety is more resistant to tobacco mosaic than the Havana No. 38 tobacco. 
TABLE IV-THE CONCENTRATION OF THE TOBACCO-MOSAIC VIRUS IN HAVANA No. 38 PLANTS, 13 WEEKS OLD; JUICE EXTRACTED NINE WEEKS AFTER INOO. ULATION; LESIONS PER $10 \mathrm{SQ}$. CM. OF LEAF SURFACE OF N. GLUTINOSA.

\begin{tabular}{|c|c|c|}
\hline No. of lesions & $d^{2}$ & M \\
\hline 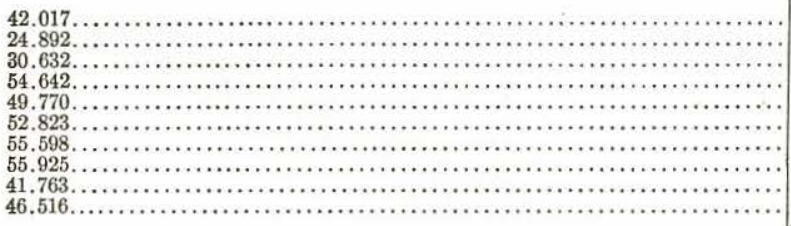 & $\begin{array}{r}11.8405 \\
422.9604 \\
219.8103 \\
84.3459 \\
18.5933 \\
54.2432 \\
102.8196 \\
109.5581 \\
13.6530 \\
1.1194\end{array}$ & 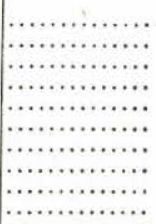 \\
\hline 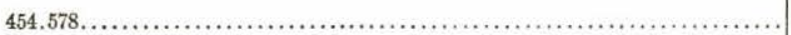 & 1038.9437 & $45.458 \pm 2.292$ \\
\hline
\end{tabular}

\section{Age of Plant and Virus Concentration}

It was deemed advisable to determine if the virus concentration in the tissues of plants would undergo any changes with age of plant. For this purpose small plants were inoculated when four weeks old and the concentration of the virus was determined by extracting the juice five and nine weeks after inoculation and testing on $N$. glutinosa. Plants were properly numbered so that the same plant could be studied at the two ages given herein. The results appear in Table V.

TABLE V-COMPARISON OF THE VIRUS CONCENTRATION IN AMBALEMA PLANTS NINE AND THIRTEEN WEEKS OLD; JUICE EXTRACTED AT FIVE AND NINE WEEKS AFTER INOCULATION; LESIONS PER 10 SQ. CM. OF LEAF SURFACE OF N. GLUTINOSA.

\begin{tabular}{|c|c|c|c|c|c|}
\hline Plant No. & $\begin{array}{l}\text { Five weeks } \\
\text { after } \\
\text { inoculation }\end{array}$ & $\begin{array}{l}\text { Nine weeks } \\
\text { after } \\
\text { inoculation }\end{array}$ & $d^{2}$ & M & S. D. \\
\hline 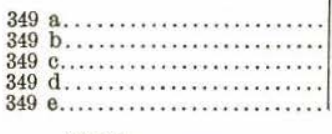 & $\begin{array}{l}14.241 \\
17.077 \\
17.953 \\
17.139 \\
15.103\end{array}$ & $\begin{array}{l}1.609 \\
5.033 \\
5.103 \\
7.150 \\
5.016\end{array}$ & $\begin{array}{l}0.626630 \\
0.041453 \\
6.810012 \\
3.427682 \\
3.074412\end{array}$ & 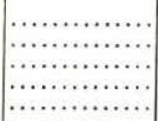 & 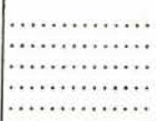 \\
\hline Total ............... & & & 13.980189 & 11.8404 & 1.6712 \\
\hline
\end{tabular}

The value of $\mathrm{Z}$ was found to be 7.085 which may be taken as 7.1. This value with $n=5$, gives odds higher than 9999:1 that the difference is not due to chance alone, thus leading to the conclusion that the virus concentration in the resistant plant is lower in plants 13 weeks old than in the same plants at nine weeks of age.

Using Bessel's method for the determination of the probable error and the significance of results, the concentration of the virus at different ages of the plant was studied on the basis of 20 plants of the Ambalema variety. The mean number of local lesions produced by the juice of Ambalema plants five weeks after inoculation was 
$18.006 \pm 0.875$ (Table VI) and that by the juice of the same plants nine weeks after inoculation was $4.828 \pm 0.468$ (Table VI). The difference of these two observations is $13.178 \pm 0.992$. This difference is 13.28 times as great as its probable error and therefore can well be attributed to an actual difference in the concentration of the virus in the resistant plant at an age of nine and thirteen weeks and not to chance.

TABLE VI-COMPARISON OF THE VIRUS CONCENTRATION IN AMBALEMA PLANTS NINE AND THIRTEEN WEEKS OLD; JUICE EXTRACTED AT FIVE AND NINE WEEKS AFTER INOCULATION; LESIONS PER 10 SQ. CM. OF LEAF SURFACE OF N. GLUTINOSA.

\begin{tabular}{|c|c|c|c|c|c|c|}
\hline \multirow{2}{*}{ Plant No. } & \multicolumn{3}{|c|}{ Plants 5 weeks after inoculation } & \multicolumn{3}{|c|}{ Plants 9 weeks after inoculation } \\
\hline & $\begin{array}{l}\text { No. of } \\
\text { lesions }\end{array}$ & $\mathrm{d}^{2}$ & $\mathrm{M}$ & $\begin{array}{l}\text { No. of } \\
\text { lesions }\end{array}$ & $\mathrm{d}^{2}$ & M \\
\hline 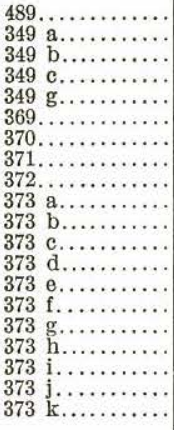 & $\begin{array}{r}2.678 \\
14.241 \\
17.077 \\
17.953 \\
17.139 \\
19.499 \\
21.128 \\
25.961 \\
26.660 \\
17.257 \\
12.342 \\
18.671 \\
23.661 \\
15.003 \\
9.766 \\
27.167 \\
17.424 \\
18.037 \\
17.113 \\
21.339\end{array}$ & $\begin{array}{r}234.9476 \\
14.1752 \\
0.8630 \\
0.0028 \\
0.7517 \\
2.2290 \\
9.7469 \\
63.2820 \\
74.8917 \\
0.5610 \\
32.0809 \\
0.4422 \\
31.9790 \\
9.0180 \\
67.8976 \\
83.9239 \\
0.3387 \\
0.0010 \\
0.7974 \\
11.1089\end{array}$ & 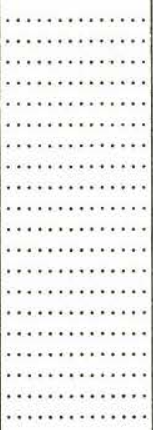 & $\begin{array}{r}10.237 \\
4.215 \\
3.328 \\
4.493 \\
4.327 \\
10.909 \\
1.609 \\
5.033 \\
5.103 \\
7.150 \\
5.016 \\
0.159 \\
0.324 \\
1.874 \\
1.080 \\
2.751 \\
8.476 \\
7.132 \\
8.012 \\
5.322\end{array}$ & $\begin{array}{r}29.2573 \\
0.3758 \\
2.2500 \\
0.1122 \\
0.2510 \\
36.9786 \\
10.3620 \\
0.0420 \\
0.0756 \\
5.3917 \\
0.0353 \\
21.7996 \\
20.2860 \\
8.7261 \\
14.0475 \\
4.3139 \\
13.3079 \\
5.3084 \\
10.1379 \\
0.2440\end{array}$ & 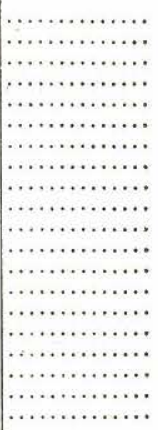 \\
\hline Total.... & 360.116 & 639.0385 & $18.006 \pm 0.875$ & 96.550 & 183.3028 & $4.828 \pm 0.468$ \\
\hline
\end{tabular}

\section{Attenuation}

It was thought that if the resistant plant was inherently capable of masking the symptoms or recovering from them, as well as preventing an increase of the virus such as is the case in the tissues of resistant plants, it might influence the virus principle to an extent to which this would be rendered less virulent. The attenuation of pathogenic organisms is of such common occurrence that it is well to take advantage of new materials and tools in order to make an inquiry into the possibilities that lie in the field of immunity against disease.

Attenuation of plant viruses has been reported in several eases. A change in the ordinary tobacco-mosaic virus has been induced by heat (Johnson: 11) and by the action of oxygen (Johnson and Ogden: 15). 
Attenuation of the virus that eauses the curly-top of sugar beet has been reported by Carsner $(2,3)$ and Lackey $(19,20)$ by passage through resistant plants and by Carsner \& Lackey (4) when passed through resistant varieties of sugar-beet.

From the results of Johnson \& Grant (14) it appears that passage of the ordinary tobacco-mosaic virus through Solanum atropurpureum, S. melongena, S. minialum and Martynia louisiana resulted in a lowering of the thermal inactivation point of the virus by several degrees Centigrade; between 5 and 10 degrees. The writers, however, consider that a variation of $5^{\circ} \mathrm{C}$ is not "of sufficient magnitude to be considered significant in the present state of our knowledge concerning plant viruses."

Grant (7) made four successive transfers of the ordinary tobaccomosaic virus through young plants of Phacelia whitlavia, larkspur, buckwheat, tassel flower and three transfers through French marigold, but his results showed no evidence of attenuation.

Holmes (9) reports a strain of the tobacco-mosaic virus which is masked in $N$. tabacum but otherwise indistinguishable from the latter. It behaves like ordinary tobaceo mosaic in response to heat, storage, dilution, suscept range and in production of necrotic symptoms.

Kunkel (18) has recently reported three attenuated strains of the aucuba mosaic of tomato, isolated from plants incubated at high temperatures and three strains of the ordinary tobacco mosaic obtained in a similar manner.

An experiment was made for the purpose of determining the effect of passage of the ordinary tobacco-mosaic and the yellow tobaccomosaic viruses through the resistant variety Ambalema.

Two series, $R^{n}-S^{n}$, involved the inoculation of resistant $(R)$ and susceptible (S) Havana No. 38 small tobacco plants at intervals of 10 days as follows: $\mathrm{R}^{1}-\mathrm{S}^{0}$, meaning the original inoculation; $\mathrm{R}^{1}$ $-S^{1}$, meaning the second inoculation, a susceptible plant inoculated with juice extracted from $R^{1}-S^{0}$; the source of inoculum for $R^{2}$ - $\mathrm{S}^{1}$ being the juice of $\mathrm{R}^{1}-\mathrm{S}^{1}$, etc.

Two other series, $R^{n}$, involved the repeated inoculation of small resistant Ambalema plants at 10-day intervals. The experiment was continued during a period of 100 days when both series ended with inoculation into a susceptible plant.

In order to test for modification of the virus, the extracted juices were inoculated into N. glutinosa and Havana No. 38 tobacco.

The results show that no change was effected in the yellow tobaceomosaic virus, that could be determined by differences in symptom expression. 
Similar results were obtained with the series in which the ordinary tobaceo-mosaic virus was used as inoculum. It should be observed that the virus was in no case exposed to the attenuating effects of the same plant, for more than ten days. If attenuation of the virus occurs, this experiment proves that a longer association than ten days is necessary between the pathogen and the protoplasm of the suscept for any change to occur. In a second experiment ten Ambalemo and five Havana No. 38 plants were inoculated at the seedling stage and kept in pots up to the blossoming stage. They were transferred repeatedly from pots and the large-plant stage was reached in ten-inch pots. The presence of the virus in the fifth leaf down from the unopened bud was determined every two weeks. The extracted juice was inoculated into Havana No. 38 tobaceo and $N$. glutinosa.

At the end of the experiment it was found that the difference in virulence of the virus had not changed significantly as indicated by the number of local lesions produced in $N$. glutinosa by the extracted juices, and by the symptoms on Havana No. 38. One exception, however, was that of an Ambalemo plant which had exhibited peculiar yellow interveinal areas on the leaves a week after inoculation. This plant was kept under special observation. Two months after inoculation, the symptoms had disappeared completely from old and new leaves. The extracted juices from this plant produced at this stage on Havana No. 38 a form of mosaic which differed in morphological symptoms from ordinary tobace mosaic or yellow tobaceo mosaic. Suspecting a mixture of viruses which might have occurred accidentally, it was conceived that by repeated inoculation into $N$. glutinosa a separation of elements producing necrosis on this suscept might be attained. Accordingly, the extracted juice from the plant was inoculated into $N$. glutinosa. No dilution was made since the concentrated juice from each lesion had been found in previous tests to produce only two or three local lesions per leaf of $N$. glutinosa. Single spots were carefully dissected out and after thorough maceration in the mortar a few drops of sterile water were added. With the aid of a little cotton wrapped at the end of dissecting needles, the small amount of extract was inoculated into a small plant of the Havana No. 38 tobacco and into a leaf of N. glutinosa. Quite surprisingly it was found that both the ordinary tobaceo mosaic and the new mild form were obtained from the single spots. The process was repeated with the mild form alone through four additional generations of $N$. glutinasa plants. The successive increase of the virus 
and repeated isolation of single spots resulted in the purification of the new virus.

It is of interest to have isolated a form of mosaic with a symptom expression different from the ordinary tobacco mosaic yet producing necrotic local lesions on $N$. glutinosw and capable of producing infection on Ambalema tobacco.

The logical procedure seemed to be to compare this form of mild mosaic with the ordinary tobacco mosaic.

Virus concentration.-A comparison of the concentration of the two viruses in Havana No. 38 and Ambalema plants was made in the way outlined at the beginning of this paper. The results appear in Tables VII and VIII.

In a series of seven observations it was found that the mean difference in concentration of the ordinary tobacco-mosaic virus and the mild-mosaic virus in Ambalema plants was 0.893 lesions with S. D. of 1.047 , which represents odds of 22.9 to 1 against this difference being due to chance alone. In a similar series of five observations in Havana No. 38, the mean difference was 11.01 with S. D. of 11.13 and odds of 16.2 to 1 . In both cases the odds are too low, indicating an insignificant difference. It may be concluded on the basis of these observations under the conditions of this experiment, that the ordinary tobacco-mosaic virus and the mild-mosaic virus do not differ significantly in their concentration in either resistant or susceptible plants.

TABLE VII-NUMBER OF LESIONS PER 10 SQ. CM. OF N. GLUTINOSA LEAF SURFACR PRODUCED BY EXTRACTED JUICES OF INOCULATED AMBALEMA PLAN'TS.

\begin{tabular}{|c|c|c|c|c|c|}
\hline Ordinary tobaceo mosaic & Mild Mosaic & $\mathrm{d}^{2}$ & M & S. D. & $\mathrm{Z}$ \\
\hline 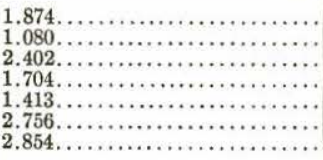 & $\begin{array}{l}0.853 \\
0.878 \\
0.450 \\
0.350 \\
2.678 \\
1.742 \\
0.880\end{array}$ & $\begin{array}{l}0.0164 \\
0.4775 \\
1.1215 \\
0.2125 \\
4.6570 \\
0.0146 \\
1.1686\end{array}$ & 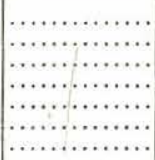 & 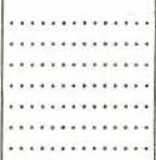 & 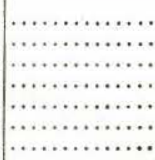 \\
\hline Total............... & & 7.6681 & 0.8931 & 1.0466 & 0.9889 \\
\hline
\end{tabular}

TABLE VIII-NUMBER OF LESIONS PER 10 SQ. CM. OF N. GLUTINOSA LEAF SURFACE PRODUCED BY EXTRACTED JUICES OF INOCULATED HAVANA No. 38 PLANTS.

\begin{tabular}{|c|c|c|c|c|c|}
\hline Ordinary tobacco mosaic & Mild Mosaic & $\mathrm{d}^{2}$ & M & S. D. & $\mathrm{Z}$ \\
\hline 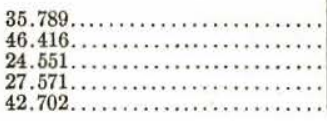 & $\begin{array}{l}22.402 \\
17.531 \\
18.741 \\
32.410 \\
35.746\end{array}$ & $\begin{array}{r}5.6501 \\
319.5156 \\
27.0400 \\
251.1908 \\
16.3539\end{array}$ & 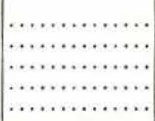 & 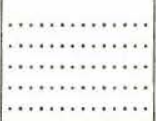 & 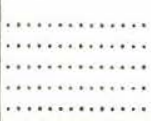 \\
\hline Total.................. & & 619.7504 & 11.010 & 11.133 & 0.853 \\
\hline
\end{tabular}


Symptoms.-The morphologic symptoms as explained above are of a mild form and unlike those of ordinary tobacco mosaic in that no leaf distortions or enations have been observed. For a clearer idea of this mosaic, see figs. 23-26.

Nothing is known of the histologic situation. Observations indicate that the physiology of plants affected with this form of mosaic must be different from those infected with the ordinary form since they are able to develop fairly well and bear good seed.

Temperature relations. - Three different experiments to determine the thermal inactivation point of the mild-mosaic virus showed that it lies between $86^{\circ}$ and $90^{\circ} \mathrm{C}$., like the checks of ordinary tobaccomosaic virus.

It was not inactivated at $85^{\circ} \mathrm{C}$. This correspondence with ordinary tobacco-mosaic virus should be of some significance in the interpretation of these results.

\section{Discussion}

A point of interest not raised in our previous paper (21) is the fact that according to current hypotheses a case of resistance to mosaic within the species $N$. tabacum would not have been expected to be very frequent. The ordinary tobacco-mosaic virus is certainly one of wide occurrence. Suffice it to mention that its host range has been recently extended by Grant (7) to include 29 non-solanaceous species distributed in 14 widely separated families. Our discovery, therefore, does not easily fall within the postulates advanced by Vavilov (25) who claimed that the chances for occurrence of immune or resistant plants would be least for species of pathogens with a weak degree of pathogenetic specialization.

The results herein presented show that plants of the Ambalema variety always become infected provided that inoculation is properly done. It has also been demonstrated that infection will occur at any age of the suscept. It is further shown that symptoms of a very mild character will appear on small plants but that the plants have the capacity to outgrow the symptoms and the new growth appears free from chlorosis. From the commercial and practical standpoint this is of more than ordinary interest. It has been generally conceded by workers with the mosaic of tobaceo that infection in the field or seed-bed arises when the workers handling the small plants have the habit of chewing tobacco. Valleau and Johnson (24) Fukushi (6) and Busch and Wolf (1) have determined by experiment that many commercial brands of tobaceo serve as sources of inoculum. 
There remains no doubt that a variety of tobaceo which can escape the injurious effects consequent to infection at the time of transplanting should prove valuable in the hands of both the practical grower and the scientific investigator. This is especially true if one bears in mind the futility of efforts in the rogueing of tobaceo-mosaic infected plants. Wolf (27) is of the opinion that the rogueing of seed-beds is inadvisable. Most investigators who have had field experience with this disease will agree that much harm will often result from this method of eradication unless the laborers are intelligent and extremely careful.

The use of the number of local lesions produced on $N$. glutinosa by the extracted juices is the only method at hand to express in quantitative terms the concentration of the virus principle in the tissues of its host; but at best it is only of relative value. A modification of the method has been made here involving the expression of concentration on the basis of measured areas, in this case ten square centimeters of leaf surface. The variety Ambalema has been considered as resistant because the measure of the virus concentration in its tissues as represented by the number of local lesions per ten square centimeters of $N$. glutinosa leaf surface has been shown to be significantly lower than that of the juice from a known susceptible variety. Other factors inherent in the plant may be responsible for the low virus concentration. The resistance in the Ambalema variety, therefore, may be defined as the capacity of the Ambalema system to prevent the increase of the virus in its tissues at the same high rate as is characteristic of susceptible plants.

The Ambalema tobacco was found to be very susceptible to other known viruses of tobaceo. It succumbs quickly to the effects of spot-necrosis and Wingard's tobaceo ring-spot and more slowly to potato ring-spot and cucumber-mosaic viruses. The degree of susceptibility is difficult to estimate in the case of the mottle and veinbanding viruses although the symptoms appear in the leaves. In these cases we may be dealing with a mild tolerance to infection. The fact that it exhibits its highest resistance to yellow tobacco-mosaic and ordinary tobacco-mosaic viruses raises an important question. Is there really so much difference between these two viruses? Johnson (12) is quite convinced that they are different, though closely related. We only wish to call attention, in passing, to the similar reaction exhibited by the resistant variety to infection by both viruses.

That the virus concentration in resistant plants was higher in plants five weeks old than in the same plants at the age of thirteen 
weeks may mean that the virus is increasing at a lower rate in the older plant. Another explanation may be that the virus principle becomes diluted with the expansion of the leaf blades. It would not be easy to conceive of the destruction of some of the virus principle in the larger and older plants.

The isolation of an apparently new virus from resistant plants inoculated with the virus of the ordinary tobaceo mosaic may be explained as a case of attenuation of the latter.

On the basis of the symptom expression alone the mild mosaic can be differentiated from the ordinary tobaceo mosaic. That the thermal inactivation point, the virus concentration and the production of local necrotic lesions is like in ordinary tobacco mosaic may indicate that the mild-mosaic virus is not very far removed from the latter. It will be a question as to whether the difference in symptom expression alone has enough weight to lead one to regard the two viruses as different from each other. Johnson (12) has already pointed out that symptoms may be of little diagnostic value in differentiating between plant viruses.

It may also be attributed to a separation of another mosaic virus or of a factor contained in the tobacco-mosaic virus. This would necessitate thinking of the tobacco-mosaic virus as a mixture of factors which may be separated from their combination. Since the known properties of the ordinary tobacco-mosaic virus are exhibited by the mild-mosaic virus and this differs from the former only in the resulting symptoms, there should be no objection to regarding the mild mosaic as an attenuated form whose parasitic and pathogenic capacity has been changed or altered in degree but not in character.

Whether this modification has been influenced by the protoplasm of the resistant plant in part or in its entirety, or whether other factors extraneous to the plant have played the major or perhaps the complete role, has not been ascertained in these studies.

\section{ACKNOWLEDGMENTS}

The writer is happy to acknowledge his appreciation for the many facilities placed at his disposal by Prof. L. M. Massey, Head of the Department of Plant Pathology and Prof. R. A. Emerson, Head of the Department of Plant Breeding, Cornell University; as well as to Prof. James G. Moore, Chairman of the Department of Horticulture and Prof. James Johnson, Tobacco Pathologist, University of Wisconsin. He is particularly indebted to Prof. Johnson for many valuable suggestions and criticisms and for his interest in these 
studies. An expression of gratitude is owed to the John Simon Memorial Foundation of New York for a grant of a fellowship and to Dr. Henry Allen Moe, Secretary of that Foundation, who was very helpful in securing approval of such changes in the plan of studies which made possible the completion of the project in Wisconsin. Finally, he wishes to express his thanks to Prof. H. H. Whetzel of Cornell University for valuable suggestions in the preparation of the manuscript.

\section{SUMMary}

1. Infection of the resistant tobaceo variety Ambalema occurs at all ages.

2. Symptoms in resistant plants ordinarily consist of clearing of the veins followed by small chlorotic interveinal areas of a mild type.

3 . Infection occurs and mild or severe symptoms appear in transplants when these are inoculated at time of pulling. These plants later recover in the field, but the virus is always contained in their tissues.

4. Infection of Ambalema plants was determined by inoculation of the juices extracted from those plants into N. glutinosa and Havana No. 38 tobacco.

5. Ambalema tobaceo is also resistant to yellow tobaceo mosaic, and celery mosaic. It should not be forgotten that symptoms are produced in inoculated plants but the effects produced by the disease are not very significant.

6. By adequate quantitative studies it was determined that the Ambalema tobacco is significantly more resistant to ordinary tobacco mosaic than Havana No. 38 tobaceo at all stages of growth.

7. Ambalema tobacco is very susceptible to cucumber mosaic, yellow cucumber mosaic, potato ring-spot, Wingard's tobacco ringspot and spot-necrosis, and somewhat less susceptible to the mottle and veinbanding viruses.

8. The virus concentration was found to be lower in inoculated resistant plants nine weeks after inoculation (13 weeks old) than five weeks after inoculation (9 weeks old).

9. A mild form of mosaic was isolated from resistant plants inoculated with the ordinary tobacco-mosaic virus. In its properties this mosaic virus seems similar to the ordinary tobacco-mosaic virus. This may possibly be regarded as a case of attenuation.

\section{Department of Agriculture and Commerce,} San Juan, Puerto Rico 


\section{Literature Cited}

(1) Bush, H. J. and F. A. Wolf. Manufactured tobacco, a source of inoculum for mosaic in flue-cured tobacco. Phytopath. 23: 839-841. 1933.

(2) Carsner, E. Susceptibility of various plants to curly-top of sugar beet. Phytopath. 9: 413-421. 1919.

(3) - Attenuation of the virus of sugar beet curly-top. Phytopath. 15: 745-757. 1925.

(4) - and C. F. Lackey. Further studies on attenuation of the virus of sugar beet curly-top. Phytopath. 18: 951. 1928. (Abstract)

(5) Fromme, F. D., E. A. Wingard and C. N. Priode. Ring spot of tobacco, an infectious disease of unknown cause. Phytopath. 17: 321-328. 1927.

(6) Fukushi, Teikichi. On the modes of transmission of the mosaic disease of tobacco. Jour. Sapporo Soc. Agr. \& Forestry 22: 305-320. 1931. (Japanese with English summary.)

(7) Grant, T. J. The host range and behavior of the ordinary tobacco-mosaic virus. Phytopath. 24: 311-336, fig. 1-3. 1934.

(8) Holmes, Francis 0. Local lesions in tobacco mosaic. Bot. Gaz. 87: 39-55, fig. 1-11. 1929.

(9) - Masked strains of tobacco-mosaic virus. Phytopath. 24: 11. 1934. (Abstract).

(10) Johnson, James. Transmission of viruses from apparently healthy potatoes. Univ. of Wisconsin Agr. Exp. Sta. Res. Bul. 63: 1-12, pl. 1-8. 1925.

(11) . The attenuation of plant viruses and the inactivating influence of oxygen. Science, N. S., 64: 210. 1925.

(12) The classification of plant viruses. Univ. of Wisconsin Agr. Exp. Sta. Res. Bul. 76: 1-16, pl. 1-8. 1927.

(13) The classification of certain virus diseases of the potato. Univ. of Wisconsin Agr. Exp. Sta. Res. Bul. 87: 1-24, fig. 1-6. 1929.

(14) and T. J. Grant. The properties of plant viruses from different host species. Phytopath. 22: 741757. 1932.

(15) and W. B. Ogden. The over-wintering of the tobacco-mosaic virus. Wisconsin Agr. Exp. Sta. Res. Bul. 95: 1-25. 1929.

(16) Koch, Karl. The potato rugose mosaic complex. Science, N. S. 73: 615. 1931.

(17) - The nature of potato rugose mosaic. Phytopath. 23: 319-342, fig. 1-4. 1933. 
(18) KunkeI, I. O. Studies on acquired immunity with tobacco and aucuba mosaics. Phytopath. 24: 437-466, fig. 1-7. 1934.

(19) Lackey, C. F. Attenuation of curly-top virus by resistant sugar beets which are symptomless carriers. Phytopath. 19: $975-977.1929$.

(20) - Further studies of the modification of sugar beet curly-top virus by its various hosts. Phytopath. 19: 1141-1142. 1929. (Abstract).

(21) Nolla, J. A. B. and A. Roque. A variety of tobaceo resistant to ordinary tobacco mosaic. Puerto Rico Jour. Dept. Agr. 17: 301-303. 1933.

(22) Price, W. C. Acquired immunity to ring-spot in Nicotiana. Cont. Boyce Thompson Inst. 4: 359-403, fig. 1-19. 1932.

(23) Roque, A. Letter of 1933.

(24) Valleau, W. D. and E. IVI. Johnson. Commercial tobaceos and cured leaf as a source of mosaic disease in tobacco. Phytopath. 17: 513-522. 1927.

(25) Vavilov, N. I. Immunity of plants to infectious diseases. Izv. Petrovsk. Selskokhoz. Akad.: 1-239. (Russian with Engłish résumé, pages 221-239). 1918.

(26) Wellman, F. L. Identification of celery virus 1 , the cause of southern celery mosaic. Phytopath. 24: 695-725, fig. 1-6. 1934.

(27) Wolf, F. A. Roguing as a means of control of tobaceo mosaic. Phytopath. 23: 831-833. 1933.

\section{Explanation of Plates}

Plate I.-Ordinary tobaceo mosaic.

Fig. 1. Clearing of veins, early stage, Ambalema leaf.

2. Advanced stage of infection, leaf of Ambalema tobacco.

3. Virulent form of infection with much yellowing, $A m$ balema tobacco.

4. Uninoculated check, Havana No. 38 tobacco.

Plate II.-Ordinary tobaceo mosaic. (Plants of same age.)

Fig. 5. Inoculated check, Havana No. 38 tobacco.

6. Uninoculated check, Ambalema tobacco.

7. Advanced stage of infection, Ambalema tobacco.

Plate III.-Ordinary tobacco mosaic. (Plants six weeks old.)

Fig. 8. Leaves from infected plant of Ambalema.

9. Leaves from infected plant of Havana No. 38.

Plate IV.-Ordinary tobacco mosaic. (Plants of same age.)

Fig. 10 and 12 . Infected Ambalema plants.

11. Uninoculated check, Ambalema plant. 
Plate V.-Ordinary tobaceo mosaic. (Plants of same age.)

Fig. 13. Infected plant, Havana No. 38.

14. Infected plant, Ambalema.

Plate VI.-Various virus diseases on Ambalema.

Fig. 15. Leaf infected with the yellow tobacco-mosaic virus. (Note tendency of yellow areas to be more conspicuous along margin of blade.)

16. Leaf infected with Wingard's tobaceo ring-spot virus.

17 and 18. Leaves infected with the yellow cucumber-mosaic virus.

19. Uninoculated check, leaf of Ambalema.

Plate VII.-Cucumber mosaic on Ambalema. (Plants inoculated in greenhouse and transplanted to the garden.)

Fig. 20 and 22. Plants infected with the cucumber-mosaic virus.

21. Check plant, infected with the ordinary tobaceo-mosaic virus.

Plate VIII.-Attenuation of the ordinary tobaceo-mosaic virus.

Fig. 23 and 26. Leaves of Havana No. 38 tobaceo showing symptoms of an attenuated form of tobaceo mosaic.

24. Uninoculated check. Havana No. 38 tobacco.

25. Inoculated check, Havana No. 38 tobaceo inoculated with the ordinary tobacco-mosaic virus. 
Plate I
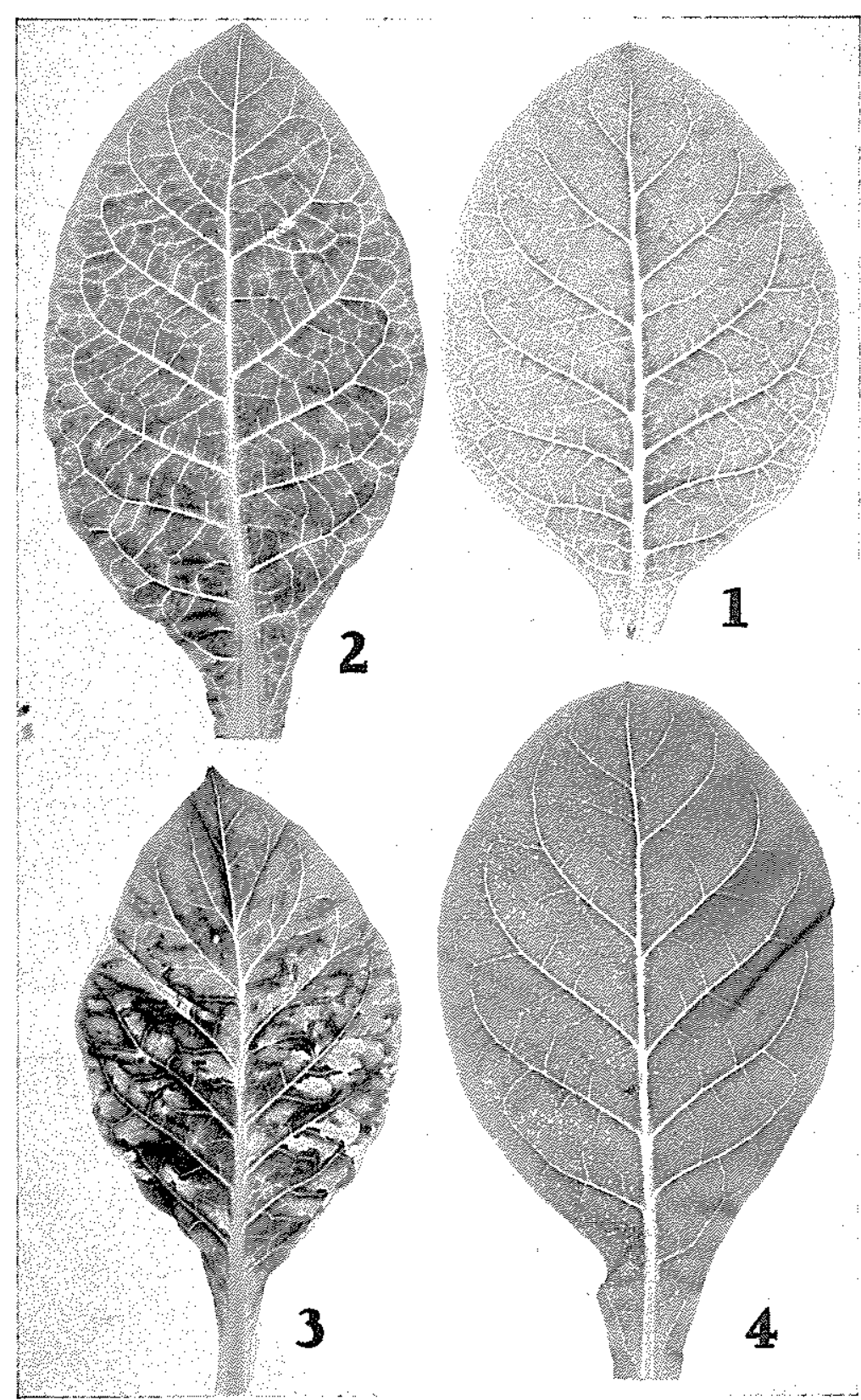
Plate II
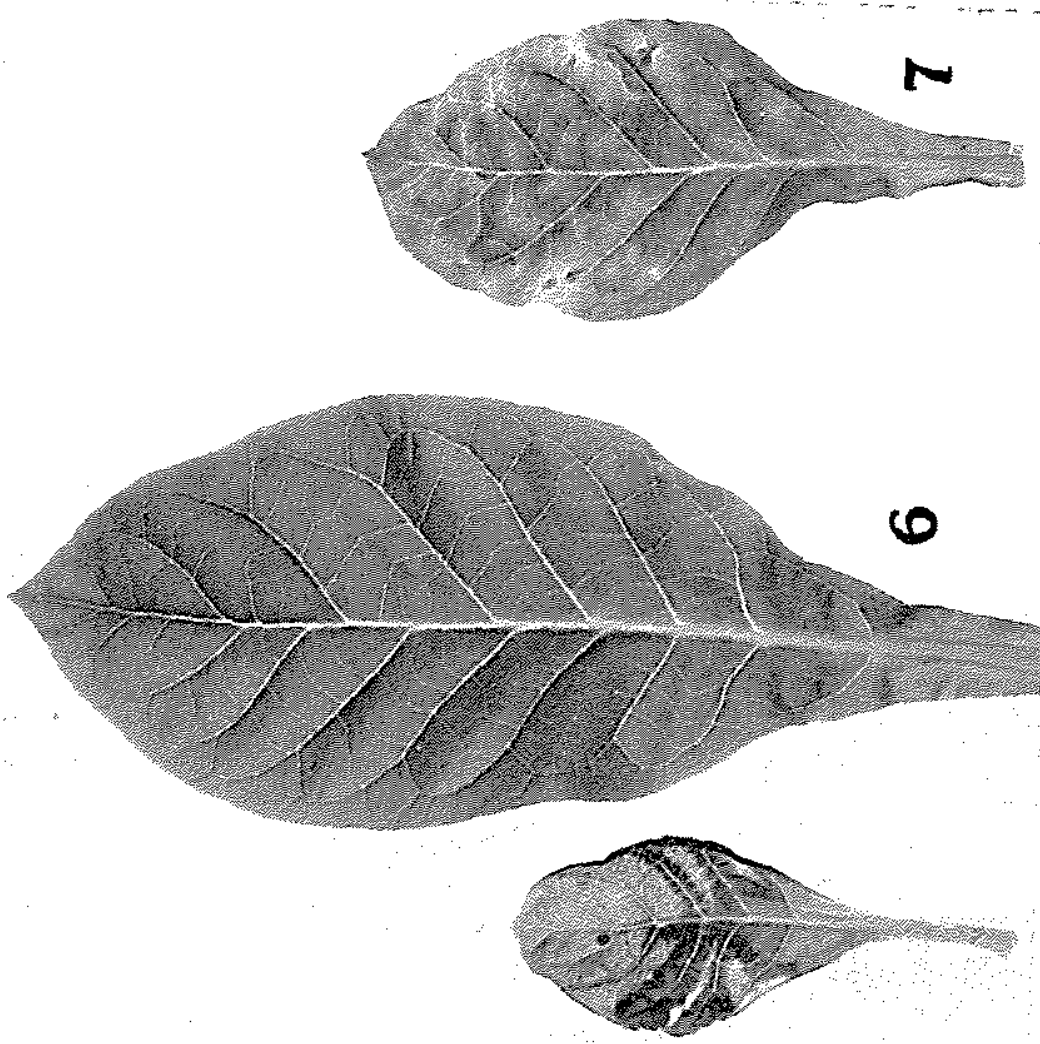

In

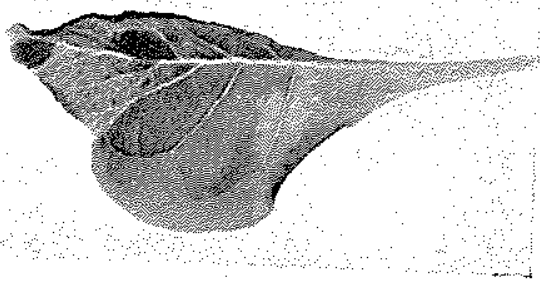


Plate III

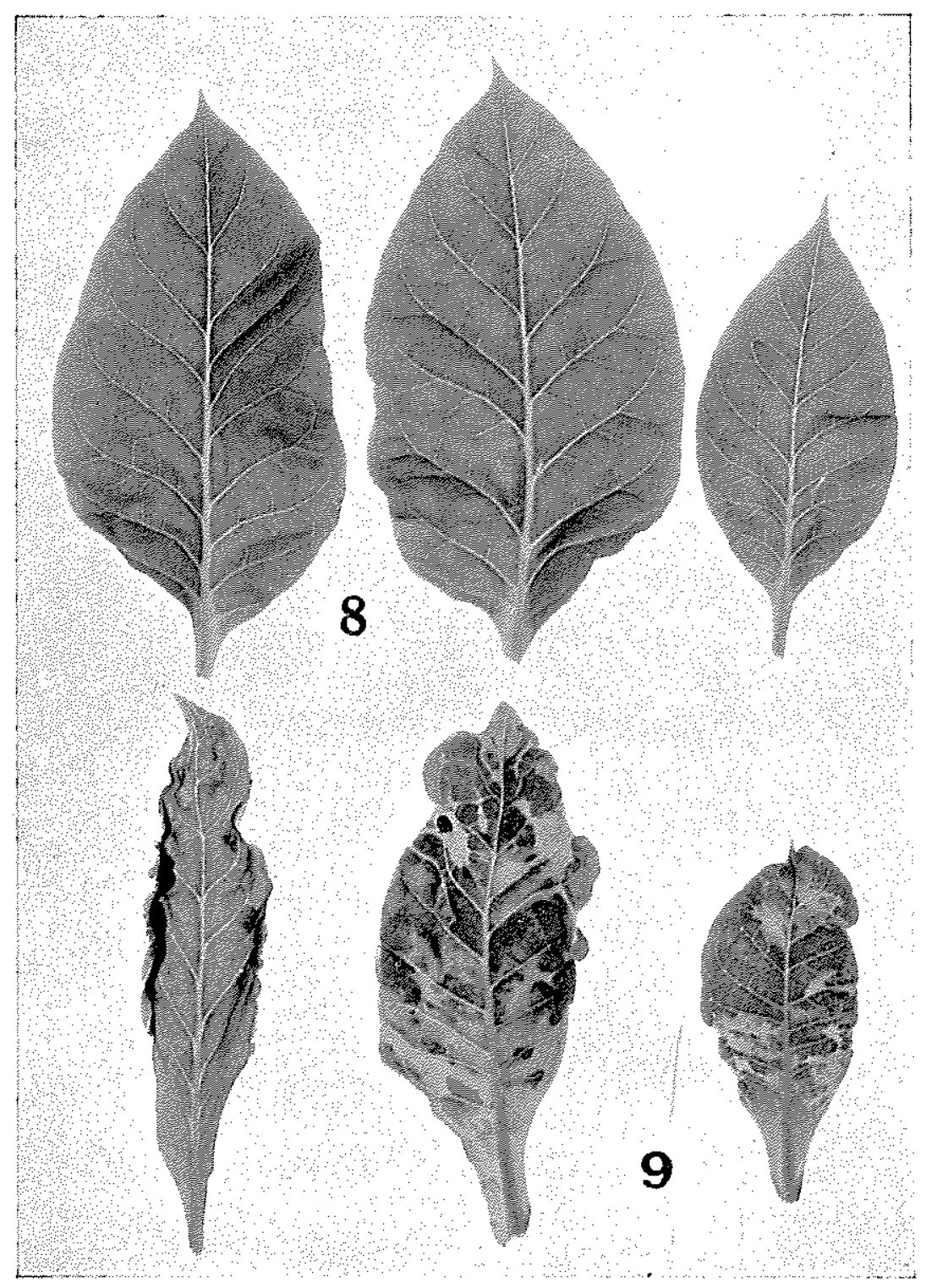




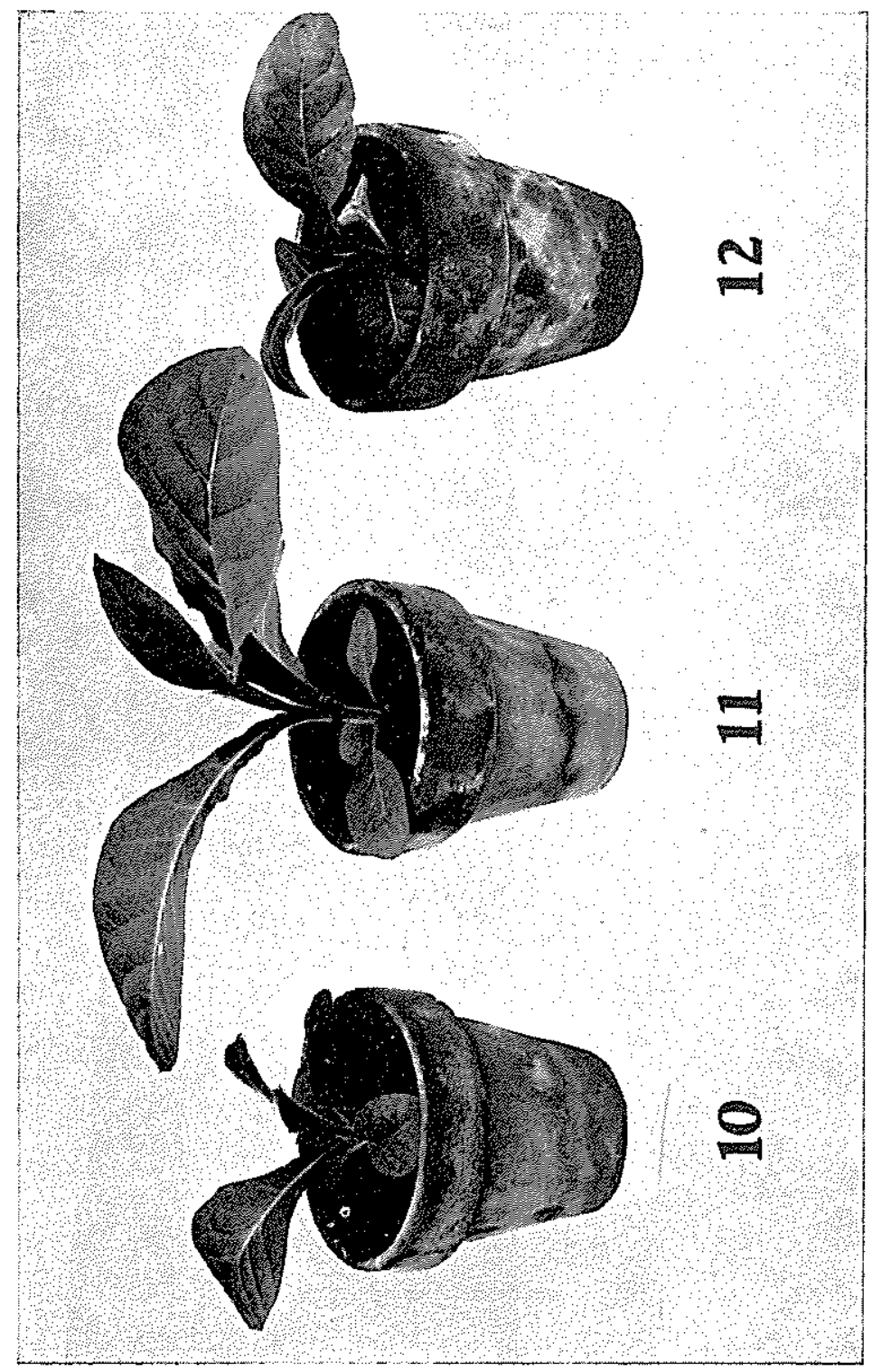




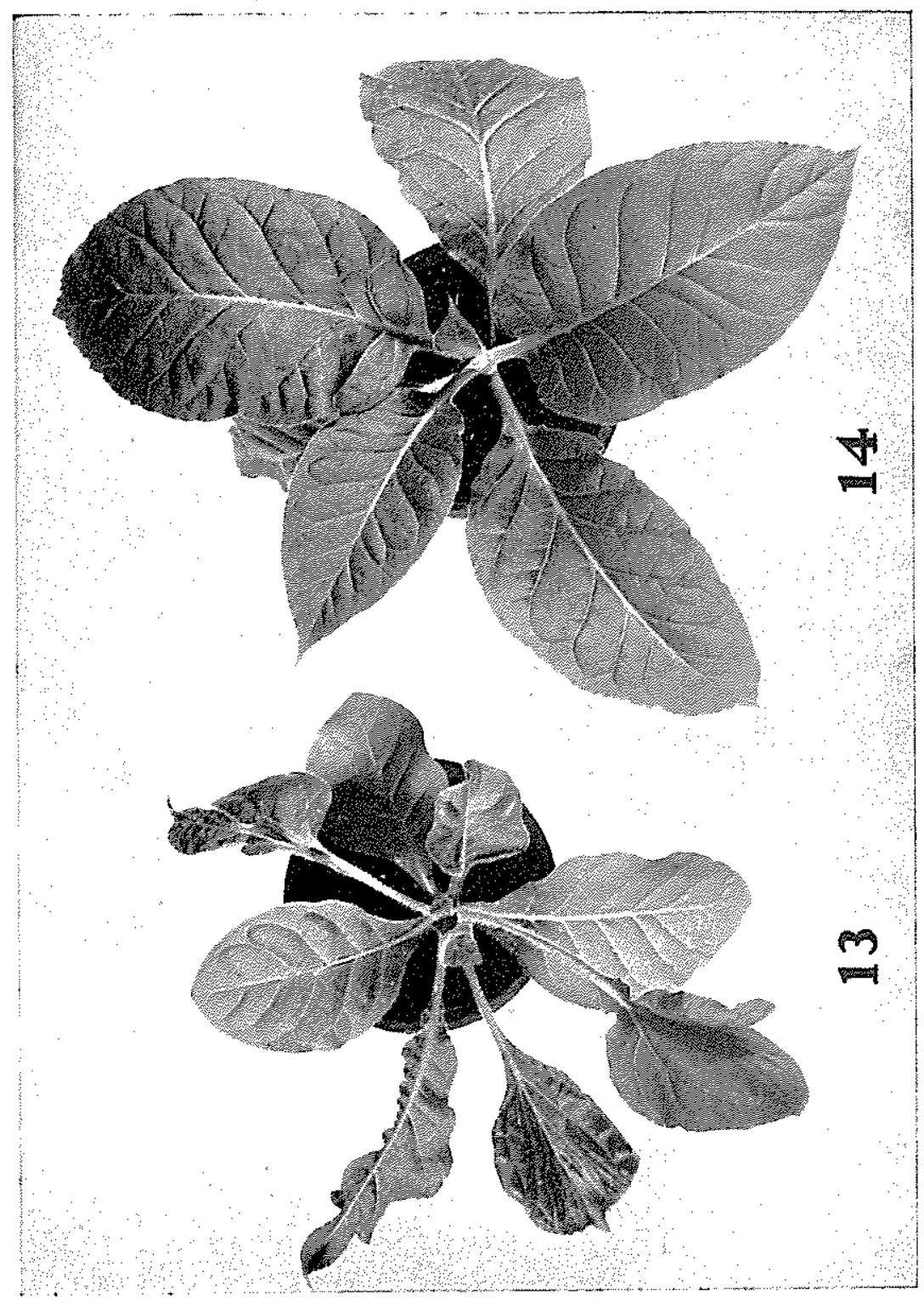


Plate VI

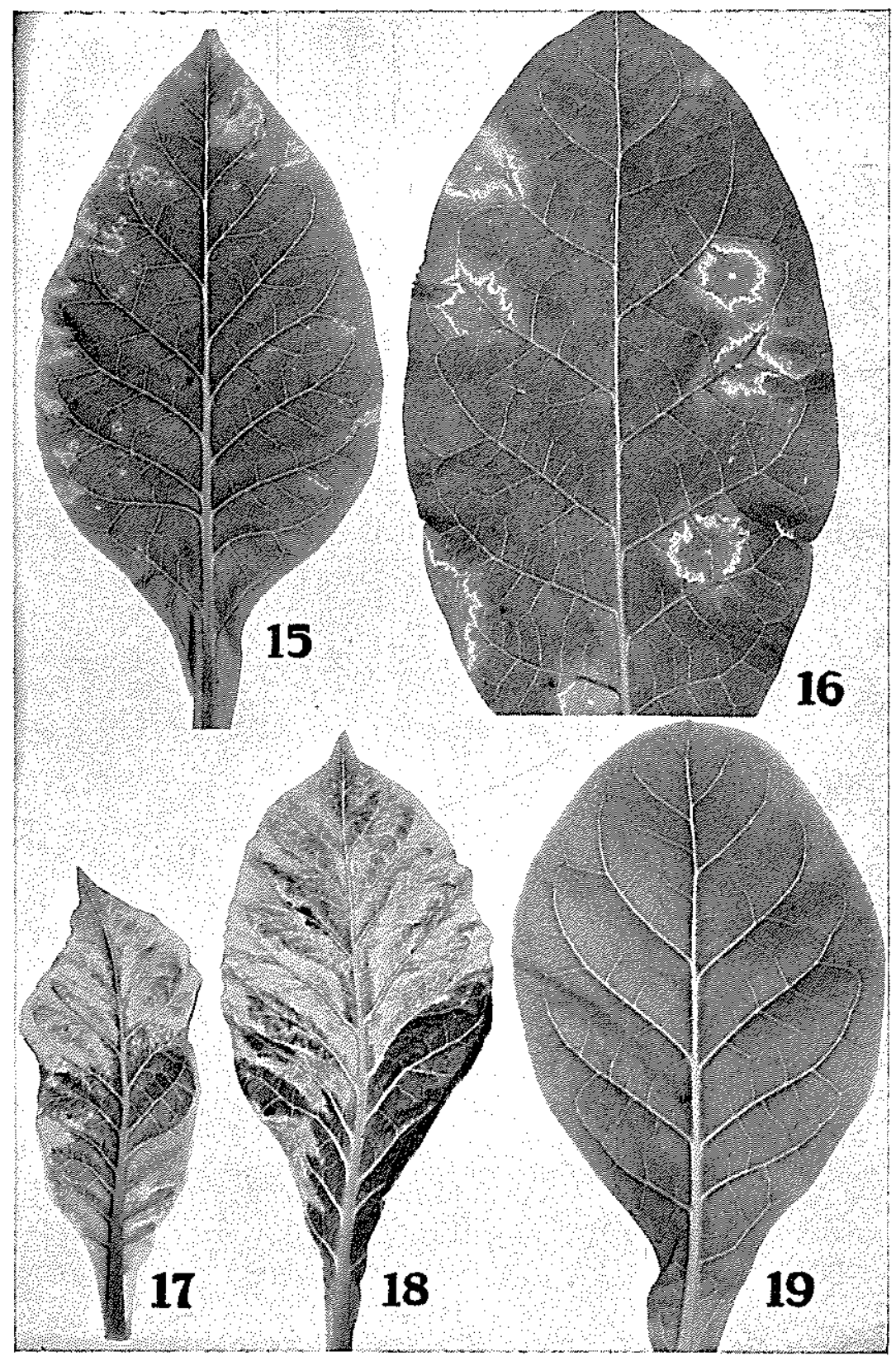




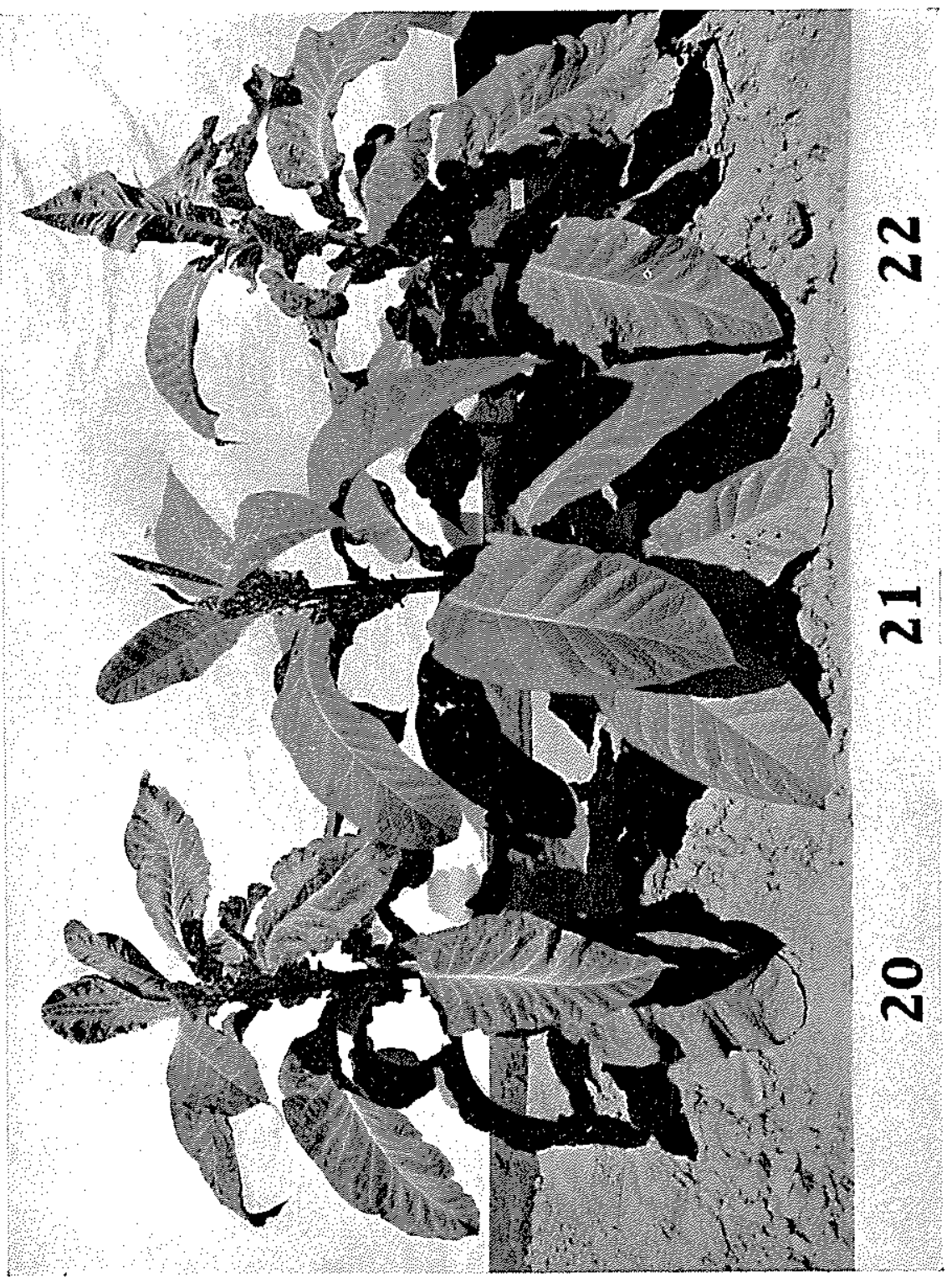




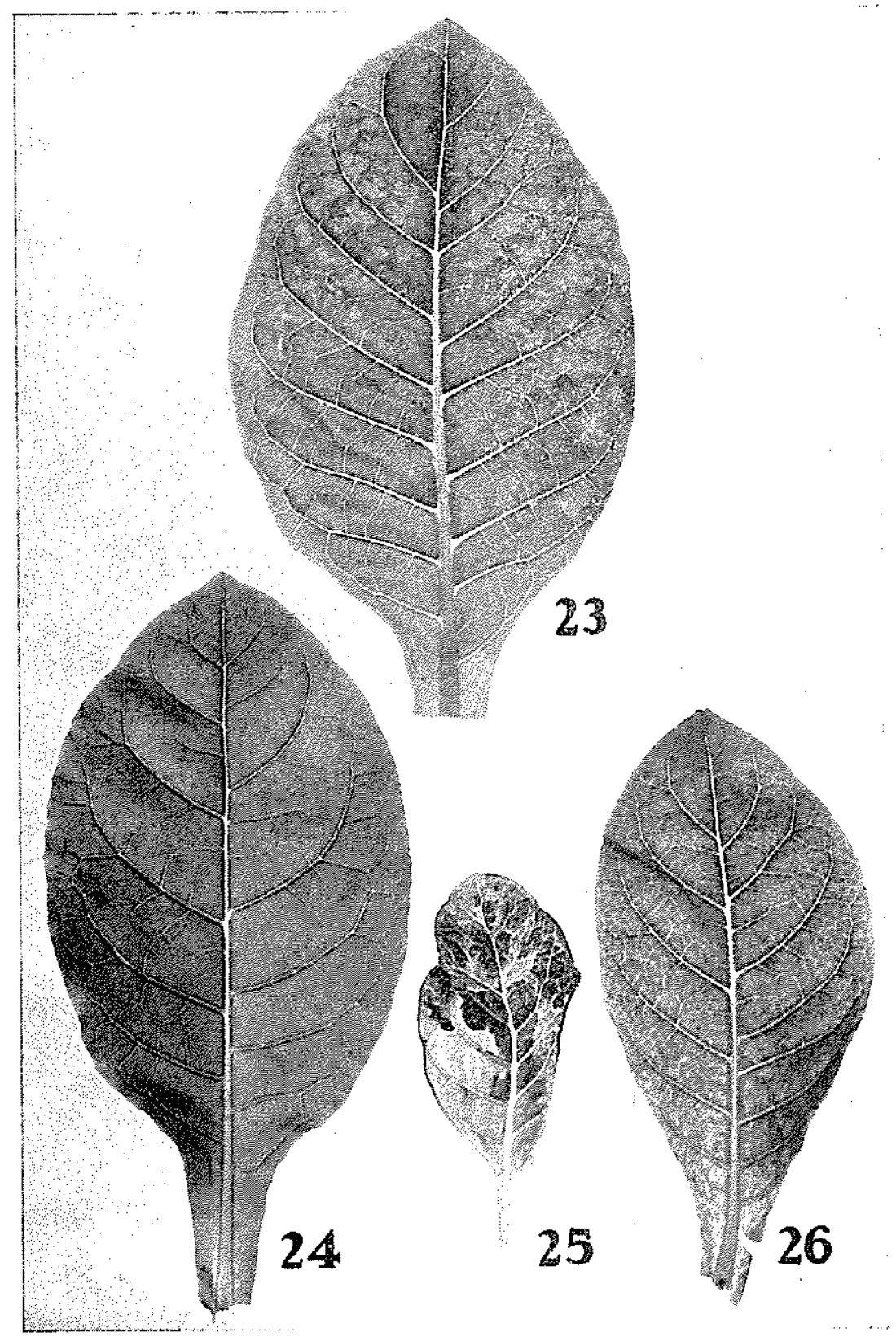




\section{PART II.-A NEW PARASITIC FUNGUS IN THE ROOTS OF SUGAR CANE}

This fungus was found on the roots of sugar cane growing in pots, while the writer was studying another disease. The writer did not make a microscopic examination of the roots at the time but put a large number in a killing fluid for later study. Therefore, the disease was not recognized as new until after the roots had been sectioned and stained. Upon the discovery that the fungus was new to science, the writer made a search for additional material in order to study living material but without success. Therefore, these studies are based entirely on material that had been sectioned and stained. However, there was a sufficient amount of material for study.

The material was killed in weak Flemming and most of it was stained with Haematoxylon and iron-alum.

The symptoms of the disease visible to the unaided eye are of little or no importance for diagnostic work. They appear as small reddish spots which cannot be distinguished from spots due to other causes. The fungus is restricted to the younger parts of the roots. It is doubtful if it ever attacks a root more than $11 / 2$ inch back of the tip.

The importance of the disease cannot be determined until a more thorough study can be made. The fungus was found in great abundance in some roots and had completely destroyed the contents of many cells. It was found on four varieties, growing in pots and well supplied with water. They are Uba, M 28, PR-801, POJ-2878, SC-12(4) and BH-10(12). It was most severe on PR-801. It has not been found in the field. The nature of the disease is such that a severe outbreak might prove very destructive, The taxanomic relations of the organism are such as to indicate that it will thrive best in soil well supplied with water.

The fungus is found in the epidermal cells and cortex but has not been found in the axis-cylinder. It sometimes occurs in masses which have been estimated to contain between 150 and 200 cells, but it also occurs in single cells throughout the cortex. There is no enlargement of the host cells. The fungus appears as a plasmodial mass which almost completely occupies the cell (Figs. 1-3). In most cases there is a single mass, while in a few others there may be several of these masses. (Figs. 4-6) This mass may be vacuolar or densely granular. (Figs. 1-2). In the young stages the nuclei are 


\section{Explanation of Plates}

Figure 1.-Longitudinal section of tip of root showing axis cylinder with one row of cells that are to form a tracheary tube; cortex, epidermis and root cap.

Figure 2.-Cross section of tip of root showing axis cylinder and a circle of large cells that are to for tracheary tubes; cortex, epidermis and a small amount of the root cap around the margin.

Figure 3.-Cross section of root tip lower down and a little above apex showing axis cylinder, cortex, epidermis and root eap around the margin.

Figure 4.-Cross section through the root cap.

Figures 5, 10 and 11.-Cross sections of cells that are to form tracheary tubes. Note difference in protoplasmic contents.

Figure 6.- Same in state of disintegration.

Figures 7, 8 and 9.-Longitudinal sections of cells that are to form tracheary tubes.

Figure 12.-Cross section of root tip showing cortex, axis cylinder and one cell of a future tracheary tube.

Figure 13.-Cross section of a root tip showing primitive axis cylinder and cortex.

Figure 14.-Cross section of root tip showing parts of cortex, epidermis and root cap.

a.c.-axis cylinder. Cor-cortex. ep $=$ epidermis. r.c. $=$ root cap. $\mathrm{tt}=$ tracheary tube.

The photographs for figures 1 to 4 were made by Dr. Harold T. Cook. 
not visible, (Figs. 1-2) but they develop in great numbers with age (Figs. 3-4). In the great majority of cases the cell wall is thin but always distinct (Figs. 1-2) but in some cases it is very thick (Fig. 3). These thick walled cells appear to be resting spores.

The plasmodium produces a germ tube which punctures the cell walls and penetrates one to four cells, possibly more, although four was the largest number observed. (Figs. 5-23). The writer never observed the germination of more than one plasmodium in a cell. There was never more than one tube to a plasmodium and branching was observed in one ease only (Fig. 13). Most of the germinating plasmodia were large but two small ones were also observed (Figs. 12 and $14 \times$ ). Bensaude (2) reported a plug of dense protoplasm at the tip of the tube. No such plug was observed in any of the writer's preparations. The formation of the tubes and zoospores have a superficial resemblance to those of Diplophlyctis intestina as described by Karling (4).

The tubes usually grew more or less in a direct line, but there were some exception. In one case the tube grew into the form of a letter U (Fig. 15). In the great mayority of cases the tube grew in the direction of the epidermis. All the exceptions were a considerable distance from the surface. The writer is unable to say whether this indicates some type of tropism or not.

The formation of nuclei and spores was not correlated with the formation of the germ tube. Sometimes the germ tube is without any evidence of nuclei (Figs. 9, 10, 11, 12, 14 and 16) while in others the nuclei are very distinct and numerous (Figs. 7, 8, 13, 15, 17 and 20) and in still others the spores are formed before the tubes have made much progress (Figs. 18 and 19). The tubes penetrated the cell walls in all cases observed except one in which it went through the wall of its own cell and then between the walls of other cells (Fig. 16). A few cases were observed in which the germ tube was unable to penetrate the cell wall but pushed it forward (Fig. 20).

The spores are numerous, more or less spherical and uninuclear with very thin but distinct walls. In some cases the germ tube passes through the epidermis and the spores are emptied into the soil (Figs. 14 and 23) while in other cases they are emptied into another host cell.

The spores that empty into the soil, presumably penetrate the epidermal cells of the same or other roots. Bensaude (2) reports a discharge of spores directly into the soil. Actual penetration was not observed but many cases were observed in which the epidermal cells were infected (Figs. 41 to 42 ). Ciliated stages of the spores 
were not observed but many preparations showed amoeboid characters. It is possible that a study of fresh material would have shown ciliated spores.

The behavior of the organism in the host was observed in many preparations. They were amoeboid and frequently united as shown by the number of nuclei (Figs. 30-34 and 41). In some cases they tended to become filamentous (figs. 35 and 37 ) and many of them penetrated cell walls (Figs. 38 and 39). They did not grow and unite with equal rapidity (Figs. 29-39). Sometimes large plasmodial bodies were found in the same cell with spores (Figs. 29-30).

A careful study of the available material leads the writer to believe that many of the sporangial bodies mature their spores without the formation of a germ tube. The formation of tubes was not observed in any of the thick walled sporangia (Fig. 3) although a careful search was made of the adjoining sections of many of them. Yet these thick-walled sporangial bodies produced an abundance of spores.

The thick-walled spores (or sporangia) were apparently resting. Roughened, thick-walled spores (or sporangia), such as are described and figured by Woronin (6) and Bensaude (2) were observed (Fig. 48) but the writer is inclined to believe that this roughness is due to plasmolosis and shrinkage.

The possibility of a second species attracted the attention of the writer. A few sporangia were observed in which the spores were much smaller than the others (Fig. 21, 22) and many cases were observed in which small spores were germinating in the host cells (Fig. 36). These small spored sporangia were very few, but the germination and behavior of the spores appeared to be the same as in the large spored forms. The large and small spored forms were not observed to unite or have any relationship whatever.

Double infection of the large host cells by the large-spored forms was observed in many cases (Figs. 43-46. The writer's opinion is based on the fact that young sporangia and spores in various stages of development were observed in many host cells.

Abnormal sporangia were of frequence occurrence. In these cases the sporangia did not develop the spherical body but developed a worm-like structure which penetrated the walls of the host cells and produced spores in the same manner as the normal, spherical sporangia (Fig. 24-28). 


\section{Discusston}

The life history of this organism is practically the same as Olpidium, with slight variations, except that the writer has not seen flagella on the spores. It is possible that flagella are present and that they can be seen in living material. Therefore, the writer will place this species tentatively in the genus Olpidium. However, it is very evident that the species is new.

Olpidium sacchari n. sp. Sporangia usually solitary in cells of the host, spherical, multinucleate, germinating by a single tube. Zoospores numerous, uninucleate, amoeboid, uniting to form plasmodia; sporangia $2.66-3.5 \mu \mu$ resting spores spherical and thick walled. Resting spores spherical with thick, smooth walls.

Sporangium saepius in cellulis hospitis solitarium sphericum multinucleatum unico tubo germinante; zoosporae numerosae uninucleatas amoeboideae in plasmodia conjugantes; sparangia 2.66-3.5uu sporae immobiliae sphericae parietibus crassis.

\section{LiteratuRE}

1. Barrett, J. T.. Development and sexuality of some species of Olpidiosis (Cornu) Fisher. Ann. Bot. 26:209-238. 1912.

2. Bensaude, IMatilde, A species of Olpidium parasitic in the roots of tomato tobacco and cabbage. Phytopathology $13(10): 451-454$. 1923.

3. Griggs, R. F. Monochytrichum, a new genus of the Chytridiales, its life-history and eytology. Ohio Naturalist 10(3) : 44-54. 1910.

4. Karling, J. S. Studies in Chydriales-II. Contribution to the life history and occurrence of Diplophlyctis intestina (Schenk) Schreeter in cells of American Characeae. Amer. Journ. Bot. 15 (3) : 204-214. 1928.

5. Kusano, S. On the life history and eytology of a new Olpidium with special reference to the copulation of motile isogametes. Journ. Coll. Agri. Tokyo. 4:141-199. 1912. (Rev. in Trans. Brit. Myc. Soc. 4: 291-1913.

6. Woronin, II. Plasmodiophora Brassicae, Urheber der Kohlpflanhernie. Jahrb. Wiss. Botanik. 11:548-574. 1878.

\section{Explanation of Plates}

Figures 1 to 6 --Plasmodia in host cells. In figure 1 the protoplasm is vaculolate; in 2 it is dense and shows first evidence of formation of nuclei; in 3 the nuclei are prominent and the wall thick. Figures 1 and 2 will produce germ tubes but figure 3 will 
not. Figures 4, 5 and 6 show two or more sporangia in single host. cells. In figure 6 one sporangium is forming a germ tube.

Figures 7,8 and 9 show germ tubes and nuclei in various stages. of formation.

Figures 10 to 14 show sporangia of different sizes and germ tubes. Figures 10 and 13 show two undeveloped sporangia; 11 and 14 show tips of tubes of sporangia not shown in the sections; the sporangia in figures 12 and 14 are very small; the tube in figure 13 is branched. This is unusual. $\mathrm{e}=$ epidermal cells.

Figure 15.-The germ tube is curved. This is unusual.

Figure 16.-A germ tube passing between the cells instead of through them. This is unusual.

Figures 17, 18 and 19.-Zoospores in various stages of formation.

Figure 20.-A germ tube has pushed the wall of the host cell forward instead of penetrating it. This is unusual.

Figures 21 and 22.-The zoospores are very small. Note the size as compared with 19.- e = epidermal cells.

Figure 23.-An unusually long tube. e= equals epidermal cells.

Figures 24 to 28.-Abnormal sporangia.

Figure 29.-A host cell containing a large number of zoospores that have not been injected into the soil. Also one large sporangium.

Figures 30 to 34.-Host cells in which the zoospores are uniting to form sporangia.

Figures 35 to 39.-Host cells in which the sporangia are amoeboid. In figures 38 and 39 the sporangia have penetrated the walls of the host cells.

Figure 40.-Two large sporangia in adjacent cells have united and are forming a germ tube.

Figures 41, 42 and 47.-Plasmodia in epidermal cells of the host. $\mathrm{e}=$ equals epidermal cells. Apparently the zoospores penetrated from the soil.

Figures 43 to 46 .-Cells of the host in which there are sporangia of different ages, probably due to infections at different times.

Figure 48.-An irregular shapped sporangium probably due to plasmolysis. 
PLATE XI.

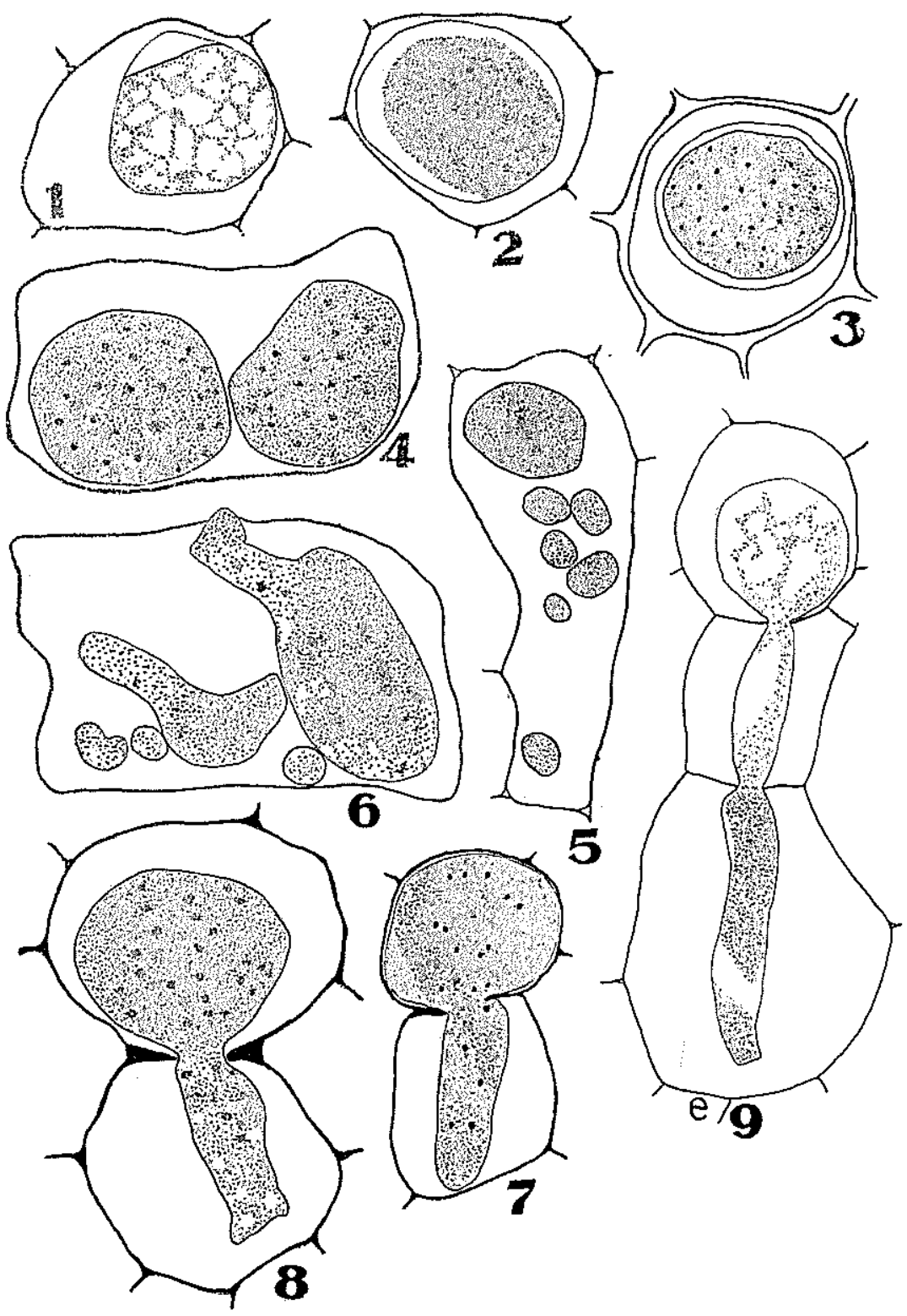




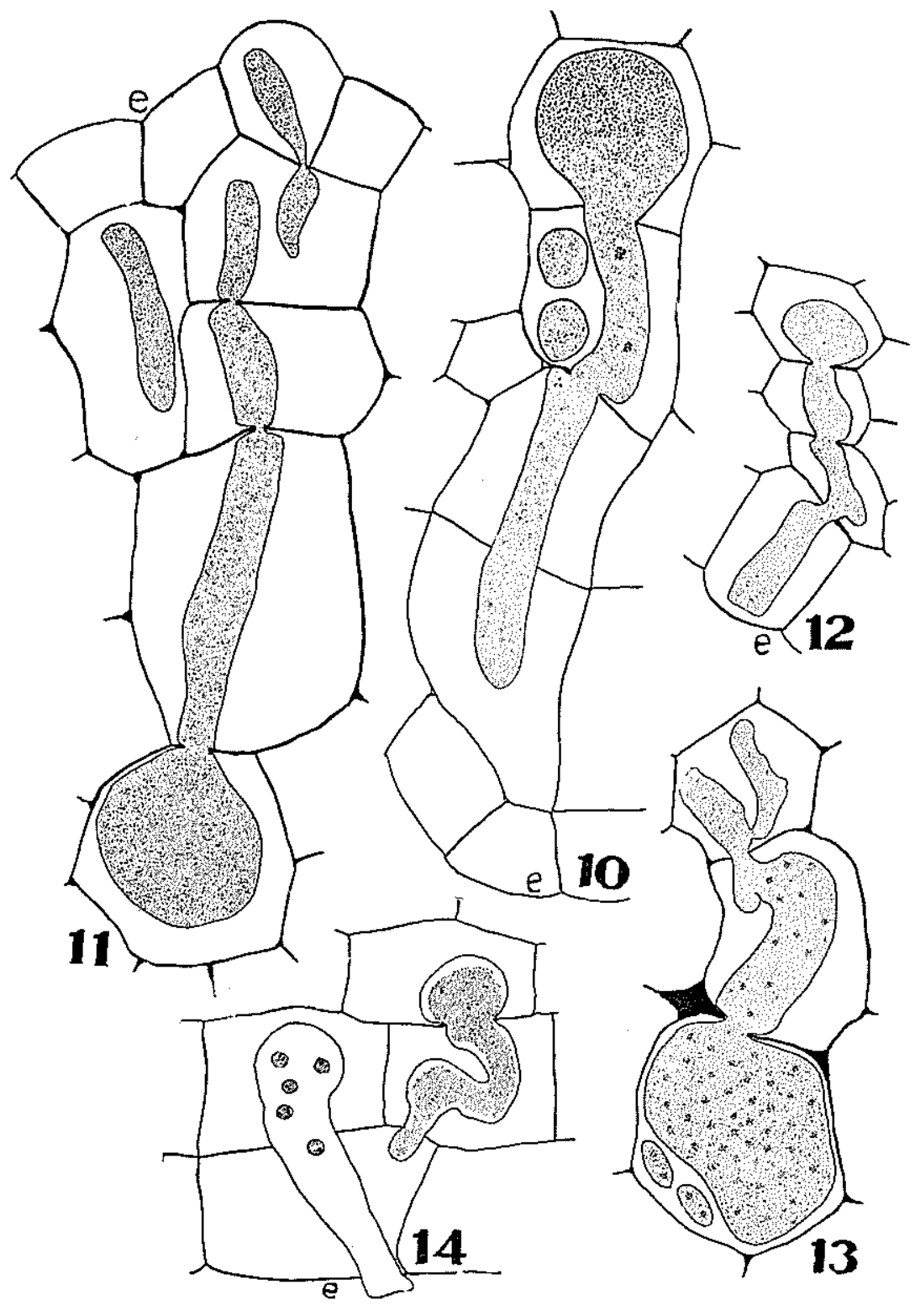




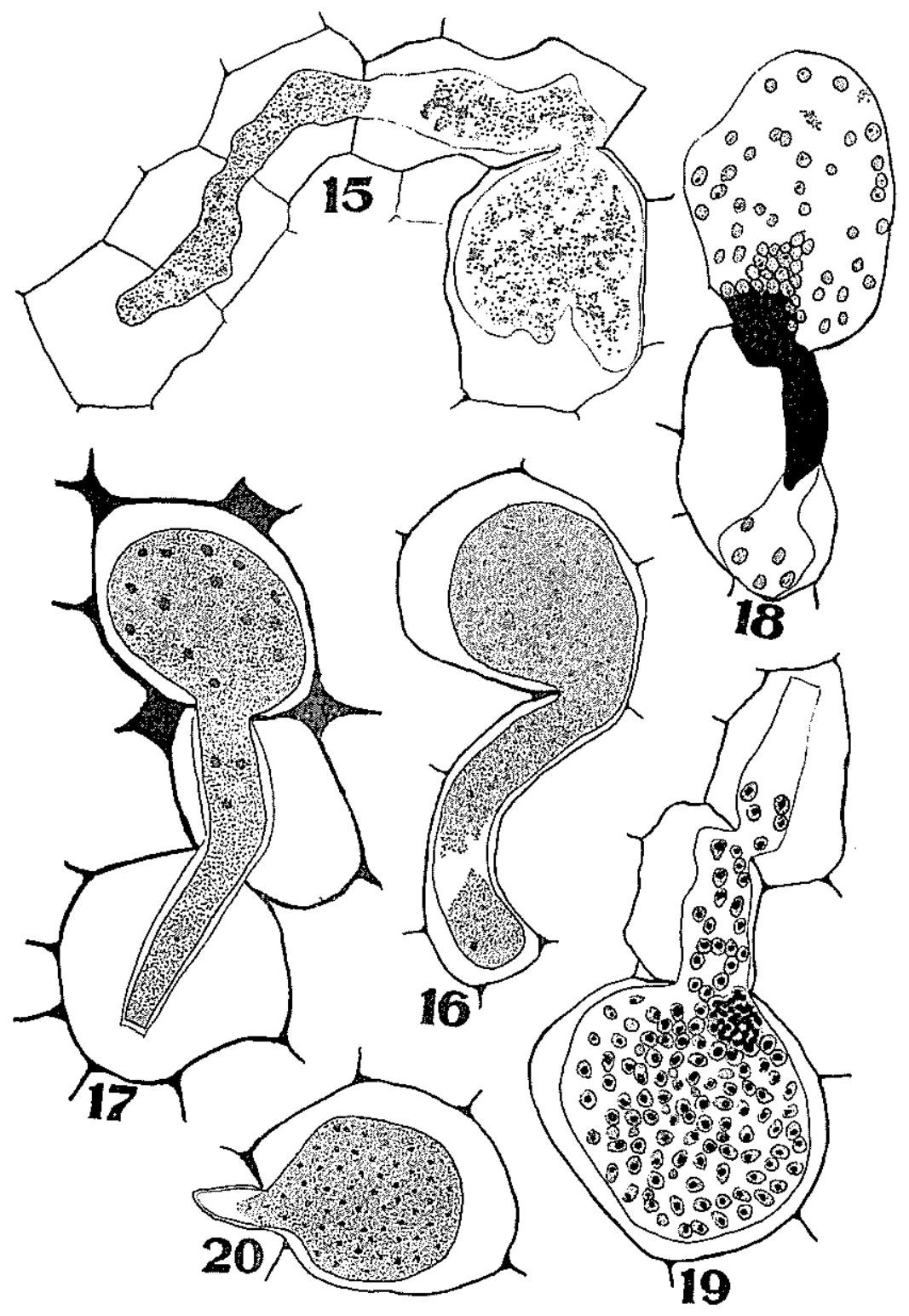




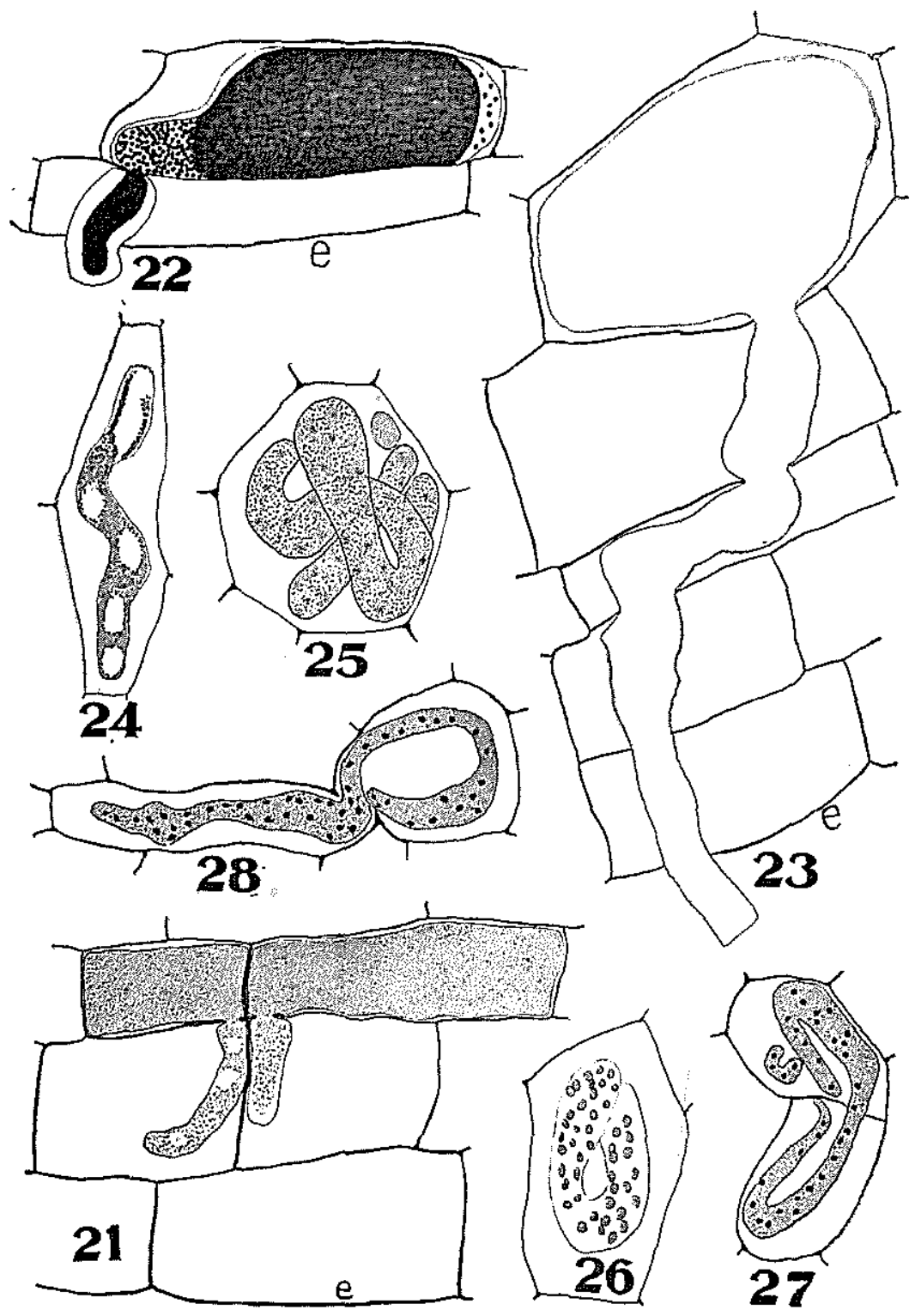




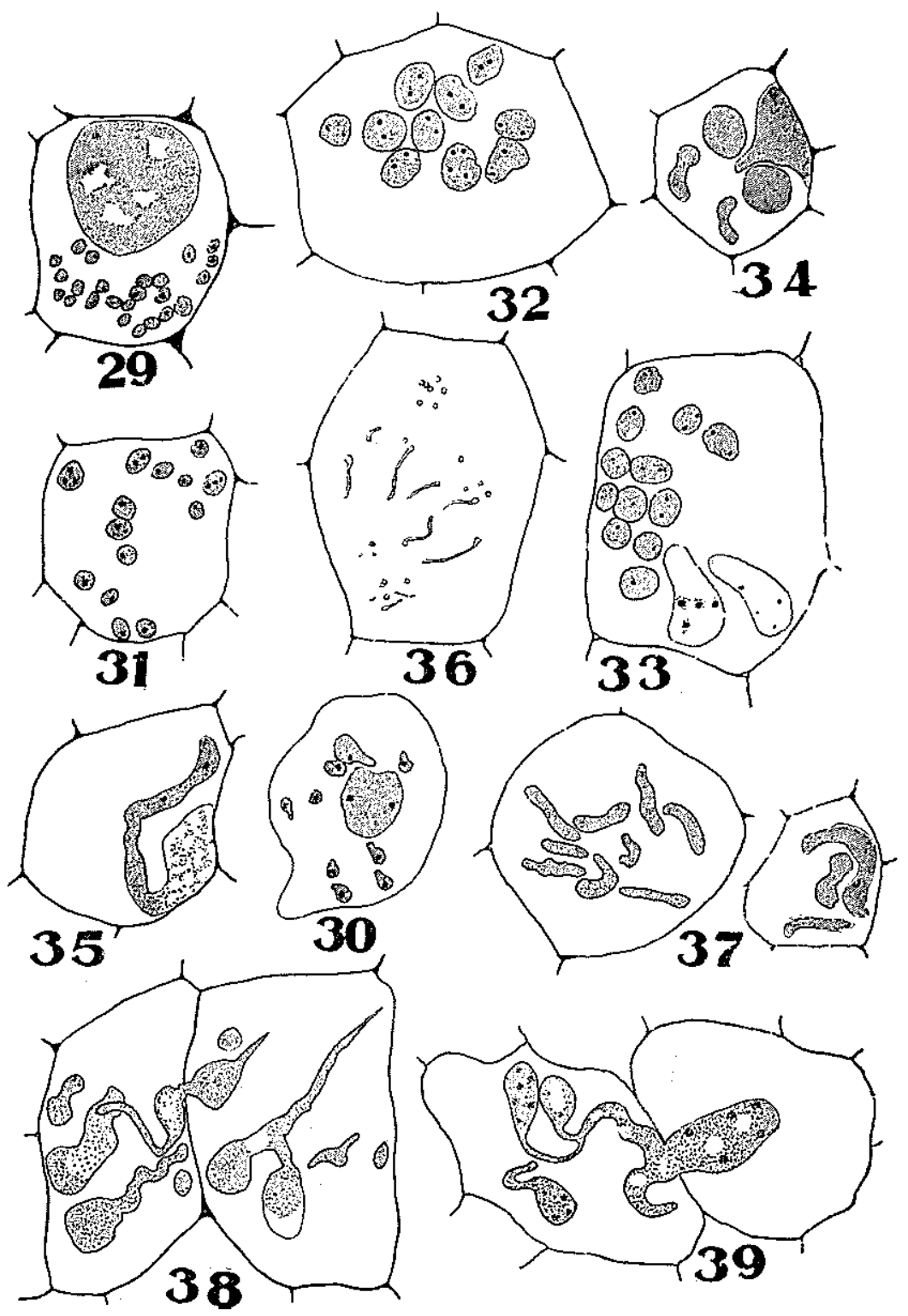




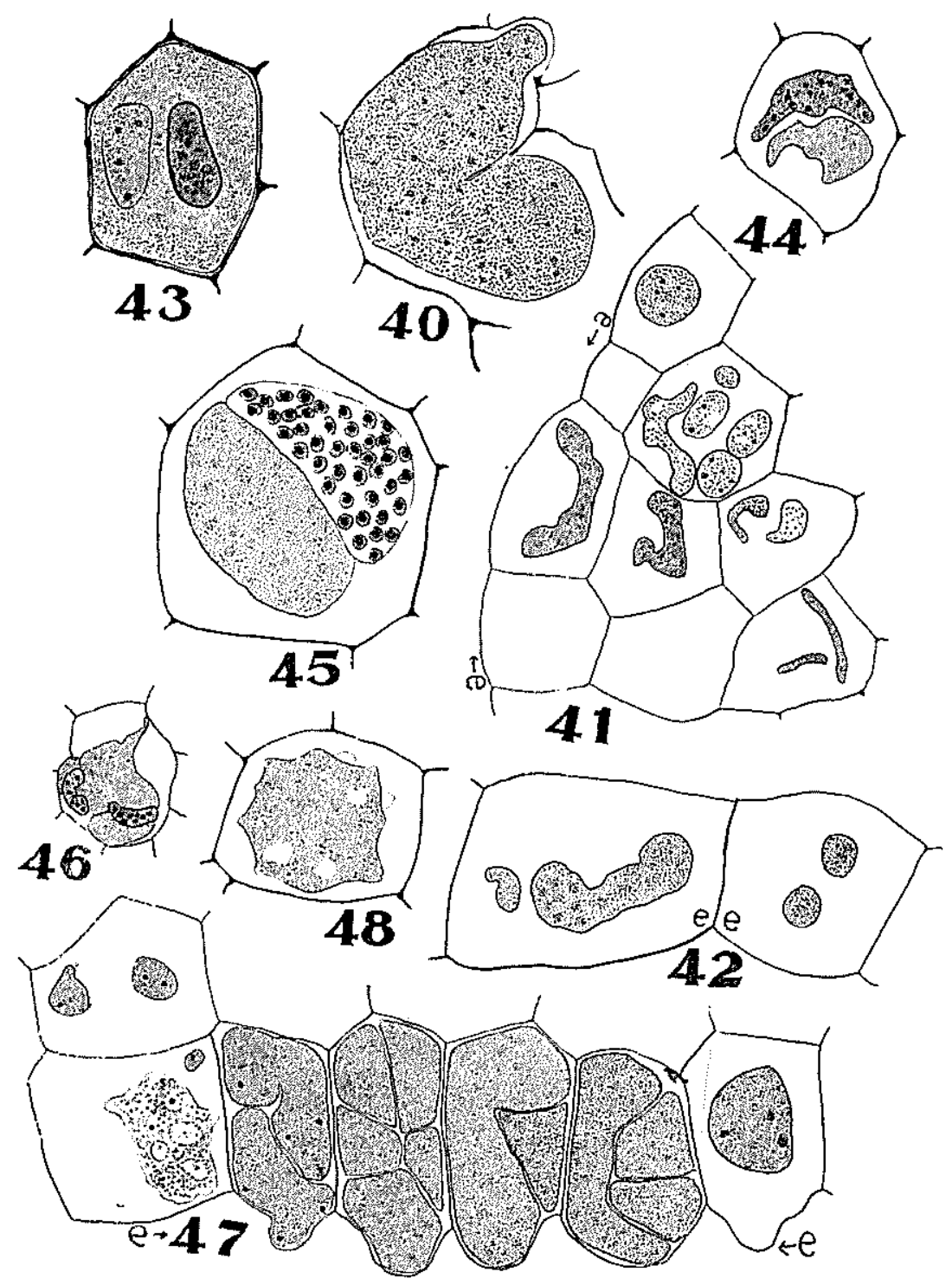

